\title{
Assessment of metal and PAH profiles in SUDS soil based on an improved experimental procedure
}

\author{
Damien Tedoldi ${ }^{1,2, *}$, Ghassan Chebbo $^{1}$, Daniel Pierlot ${ }^{2}$, Yves Kovacs $^{2}$, \\ and Marie-Christine Gromaire ${ }^{1}$
}

${ }^{1}$ LEESU, UMR MA 102, École des Ponts, AgroParisTech, UPEC, UPE, Champs-sur-Marne, 6-8 avenue Blaise Pascal, Cité Descartes, 77455 Marne-la-Vallée Cedex 2, France. damien.tedoldi@enpc.fr, chebbo@enpc.fr, gromaire@enpc.fr, +33164153769

\author{
${ }^{2}$ SEPIA, 53 rue de Turbigo, 75003 Paris, France. \\ dp@sepia-uw.fr, yk@sepia-uw.fr \\ *Corresponding author
}

\begin{abstract}
The increasing use of infiltration-based systems for stormwater management questions the soil's ability to act as a long-term filter for runoff contaminants, and brings about operational matters regarding the most effective maintenance practices to enhance contaminant retention in SUDS. This paper reports the vertical extent of metal and PAH contamination in the soil of seven source-control devices in operation for more than 10 years, assessed via a two-step sampling strategy to optimize the representativeness of the contamination profiles. Metal distribution was typically characterized by a significant surface buildup, followed by a decrease in concentrations with increasing depth, usually coming close to the background values. PAH were more heterogeneously distributed with depth, but their accumulation was globally restricted to the upper 10-40 $\mathrm{cm}$. This indicates an interesting potential for pollution interception by the upper horizons of soil, but does not necessarily prevent from downward fluxes, even while measuring low surface contents, as deeper strata may have lesser retention capacities. Specific amendments of the surface soil may help prevent this problem. Surface soil renewal - which would be necessary over 2.5 to $30 \mathrm{~cm}$ in four sites, according to the "strictest" standards for soil remediation - may regenerate the soil's sorption potential, but such a practice could disrupt the interactions with the local ecosystem, so this should be carried out exceptionally and not as a preventive measure.
\end{abstract}

KEYWORDS. Contamination profiles, Metals, Polycyclic aromatic hydrocarbons, Runoff infiltration, Spatial distribution, Sustainable Urban Drainage Systems 


\section{INTRODUCTION}

As a consequence of urban spread and soil sealing, increasing flow rates and volumes of runoff have to be managed during wet weather, showing the limitations of conventional centralized drainage systems designed to rapidly collect and convey stormwater away from urban areas (Chocat et al., 2007). In the absence of specific proscription related to the hydrogeological context, stormwater infiltration appears as an effective way to alleviate these deficiencies via decentralized, "source-control" Sustainable Urban Drainage Systems (SUDS), besides contributing to other environmental improvements such as groundwater replenishment, urban "heat island" reduction, or biodiversity aspects (Dierkes et al., 2015; Zhou, 2014). However, despite these widely recognized benefits, uncertainties remain regarding the fate of runoff contaminants within infiltration-based facilities, and the soil's retention potential towards ubiquitous urban pollutants (Mikkelsen et al., 1994). The associated operational matters relate to the definition of design and maintenance guidelines, and the identification of possible remediation measures to be prescribed on SUDS soil in order to guarantee their proper and sustainable functioning (Göbel et al., 2008).

Several experimental assessments have been carried out on existing devices, so as to address the vertical extent of soil contamination - as a representative of which most authors considered copper, lead, zinc, and cadmium in a few cases (Ganaye et al., 2007; Ingvertsen et al., 2012; Jones and Davis, 2013). Some of them included polycyclic aromatic hydrocarbons (PAH), but these pollutants still suffer from a lack of documentation in the particular context of SUDS (Dechesne et al., 2004; DiBlasi et al., 2009; Mikkelsen et al., 1996; Napier et al., 2009) - as well as other metals such as chromium, nickel, cobalt or molybdenum. Such studies, which consisted in sampling and analyzing one or several soil core(s) after a known operation time, evidenced significantly higher concentrations in the upper centimeters of soil than in the underlying samples. However, the migration depth of contaminants was found to be particularly variable from one device to another, ranging from $5-10 \mathrm{~cm}$ to $\geq 1 \mathrm{~m}$ (Tedoldi et al., 2016). These assessments were mainly achieved on large-scale, centralized infiltration basins (Barraud et al., 2005; Schroeder 1995; Winiarski et al., 2006), or bioretention systems with an engineered filter media (DiBlasi et al., 2009; Jones and Davis, 2013; Li and Davis, 2008; Paus et al., 2014). The state of the art displays a relative lack of information regarding soil contamination in source-control SUDS, such as vegetated swales or small basins, while these facilities are likely to exhibit a peculiar behavior, e.g. due to lower loads of suspended solids, higher infiltration/drainage area ratios, different 
hydrologic configurations and/or pedological contexts (Achleitner et al., 2007; Dierkes and Geiger, 1999; Ingvertsen et al., 2012).

Additionally, methodologies significantly differ from one study to another, notably regarding the sampling procedures and physicochemical analyses performed on the soil samples, as a result of which the previous observations may not be suitably intercomparable (Tedoldi et al., 2016). Although several guidelines and standards recommend to follow a two-phase sampling strategy for the investigation of urban sites (ISO 10381-5, 2005), the selection of the coring points did not systematically rely on a preliminary analysis of the contaminant distribution in the surface soil, which was yet shown to exhibit high variability at the scale of a whole infiltration system (Kluge and Wessolek, 2012; Le Coustumer et al., 2007). Consequently, some uncertainties remain about the representativeness of the aforementioned contamination profiles, especially considering the fact that they were generally derived from a unique soil core, and rarely from composite samples (Dechesne et al., 2004; Ingvertsen et al., 2012). Moreover, the vertical variations of pedological parameters were not always acquired, while several studies showed they may constitute useful data to distinguish transitions between consecutive horizons, and interpret abrupt changes in the pollutant concentrations (Mikkelsen et al., 1996; Winiarski et al., 2006).

The soil's ability to act as a long-term filter for contaminants in infiltration-based SUDS requires better understanding and further documentation in real conditions. Such an understanding would provide valuable insight into the potential use of these techniques towards water pollution control in urban environments, along with their effective lifetime, and conversely, the contexts in which stormwater infiltration should be implemented with caution. For this purpose, the present work is dedicated to characterizing both the levels and vertical extent of soil contamination in a series of SUDS, all of which have been in operation for $\geq 10$ years, on the basis of a sampling procedure aimed to optimize the representativeness of the concentration profiles. Seven source-control infiltration devices with contrasting characteristics have been investigated in this study; a total of 116 soil samples have been collected and analyzed for various urban contaminants (metals and $\mathrm{PAH}$ ) and pedological parameters. 


\section{MATERIAL AND METHODS}

\subsection{Description of the study sites}

Four small infiltration basins and three infiltration swales located in the Paris region (France) were selected for their contrasting hydrologic behaviors, soil types, and runoff contamination potentials (Table 1). The Dourdan site collects runoff water from a two-lane departmental road and a parking lot adjacent to a waste recycling center. Greffiere is implemented in a 2-ha residential catchment composed of approximately 40 houses with tile roofs. About one third of the houses have zinc gutters, and most of them have metallic rooftops and valleys, some of which are in lead. Alfortville is located downstream of an extended catchment with industrial and commercial activities. Most impervious surfaces correspond to concrete roofs, parking lots, and service roads, including a logistics area with significant truck traffic. Sausset 1 and 2 collect runoff water from two distinct parts of a car parking lot with low frequentation rate. Chanteraines adjoins a small parking lot and a service road to a logistics area, with moderate traffic mainly composed of trucks and utility vehicles. Vitry collects runoff from a T-junction in an industrial catchment, which includes several pollutant-generating activities such as a tar factory; a coal-fired power plant in the vicinity of the site has been in operation until April 2015. Photographs of the study sites are supplied as Supplementary data. Watershed delimitation was achieved via field inspection, asbuilt drawings, and cadastral data supplied by the official French web mapping service Géoportail. For each device - or sampled section in the case of longitudinal swales - the active area of the watershed was calculated as the weighted sum of the contributive surfaces, using the runoff coefficients proposed by Ellis et al. (2012).

Inflow of water consists in either inlet pipe(s) (Dourdan, Greffiere, Alfortville), or surface runoff directly flowing from the pavement over the surface soil (Sausset1, Sausset2, Chanteraines, Vitry). In Alfortville, a smaller retention basin is implemented in the upstream part of the catchment, which delays the water flow originating from approximately half of its total area. In some systems, superficial outflow is possible when the stored water exceeds a given level (Dourdan, Chanteraines, Vitry). The swales Chanteraines and Vitry were amended with planting soil during the construction works, whereas the other facilities were implemented upon the preexisting soil without any amendment. Vitry is the only site where metal concentrations were measured in the topsoil before the device started operating. In Chanteraines, the road sub-base can be found beneath the 30-cm-thick soil layer that composes the swale. In the major part of Alfortville, a dense 
clay horizon is observable around $30 \mathrm{~cm}$ depth - in spite of which the basin functions de facto as the final outlet of the drainage network. All facilities show a water table deeper than $1 \mathrm{~m}$ (based on technical studies carried out prior to their construction).

In every study site except Chanteraines and Sausset2, a dark horizon could be distinguished at the soil surface (Figure 1), whose thickness was noticed to be variable in space within a device (between 0 and $30 \mathrm{~cm}$ ) and higher near the inflow area. As discussed elsewhere (Tedoldi et al., 2017), the formation processes of this horizon probably include sedimentation and filtration of suspended solids originating from the watershed, and enhanced organic matter production in the most frequently flooded zone of the devices.

Table 1. Main characteristics of the investigated infiltration facilities

\begin{tabular}{|c|c|c|c|c|}
\hline Site name & Dourdan & Greffiere & Alfortville & Sausset1 \\
\hline Type of device & $\begin{array}{l}\text { Infiltration- } \\
\text { retention basin }\end{array}$ & Infiltration basin & Infiltration basin & Infiltration basin \\
\hline Watershed & $\begin{array}{l}\text { Road, } 4900 \\
\text { veh/day }+ \text { car } \\
\text { parking lot }\end{array}$ & $\begin{array}{l}\text { Residential, } \\
\text { metallic surfaces } \\
\text { and gutters }\end{array}$ & $\begin{array}{l}\text { Industrial }+ \\
\text { tertiary activities, } \\
4700 \mathrm{veh} / \text { day }\end{array}$ & $\begin{array}{l}\text { Car parking lot, } \\
210 \text { veh/day }\end{array}$ \\
\hline $\begin{array}{l}\text { Active area of } \\
\text { the watershed }\end{array}$ & $7000 \mathrm{~m}^{2}$ & $3000 \mathrm{~m}^{2}$ & $35000 \mathrm{~m}^{2}$ & $400 \mathrm{~m}^{2}$ \\
\hline Device area $^{\dagger}$ & $120 \mathrm{~m}^{2}(1.7 \%)$ & $65 \mathrm{~m}^{2}(2.1 \%)$ & $280 \mathrm{~m}^{2}(0.8 \%)$ & $68 \mathrm{~m}^{2}(17 \%)$ \\
\hline Inflow of water & $\begin{array}{l}\text { Pipe }(\varnothing 600 \mathrm{~mm}) \\
\text { followed by a } \\
\text { concrete apron }\end{array}$ & Pipe $(\varnothing 300 \mathrm{~mm})$ & $\begin{array}{l}\text { Two pipes }(\varnothing 800 \\
\text { and } \varnothing 300 \mathrm{~mm}) \text { at } \\
\text { each end of the } \\
\text { basin }\end{array}$ & $\begin{array}{l}\text { Direct runoff, } \\
\text { large opening } \\
(90 \mathrm{~cm})\end{array}$ \\
\hline $\begin{array}{l}\text { Superficial } \\
\text { outlet }\end{array}$ & $\begin{array}{l}\text { Elevated pipe } \\
\text { ( } 30 \mathrm{~cm} \text { above the } \\
\text { ground) }\end{array}$ & None & None & None \\
\hline Operating time & $>20$ years & 15 years & 16 years & 14 years \\
\hline Vegetation & $\begin{array}{l}\text { Spontaneous } \\
\text { vegetation }\end{array}$ & $\begin{array}{l}\text { Spontaneous } \\
\text { vegetation }\end{array}$ & $\begin{array}{l}\text { Spontaneous } \\
\text { vegetation }\end{array}$ & Shrubs and grass \\
\hline $\begin{array}{l}\text { Soil texture }(0- \\
10 \mathrm{~cm})\end{array}$ & Sandy loam & Sandy clay loam & Clay loam & Silt loam \\
\hline $\begin{array}{l}\text { Bulk density } \\
(0-5 \mathrm{~cm})\end{array}$ & $1.2 \mathrm{~kg} / \mathrm{dm}^{3}$ & $1.1 \mathrm{~kg} / \mathrm{dm}^{3}$ & $1.4 \mathrm{~kg} / \mathrm{dm}^{3}$ & $1.1 \mathrm{~kg} / \mathrm{dm}^{3}$ \\
\hline
\end{tabular}




\begin{tabular}{|c|c|c|c|}
\hline Site name & Sausset2 & Chanteraines & Vitry \\
\hline Type of device & Small swale & Swale & Swale \\
\hline Watershed & $\begin{array}{l}\text { Car parking lot, } \\
210 \mathrm{veh} / \text { day }\end{array}$ & $\begin{array}{l}\text { Road, }<1500 \\
\text { veh/day }+ \text { car } \\
\text { parking lot }\end{array}$ & $\begin{array}{l}\text { T-junction in an } \\
\text { industrial } \\
\text { watershed }\end{array}$ \\
\hline $\begin{array}{l}\text { Active area of } \\
\text { the watershed }\end{array}$ & $160 \mathrm{~m}^{2}$ & $470 \mathrm{~m}^{2}$ & $350 \mathrm{~m}^{2}$ \\
\hline Device $\operatorname{area}^{\dagger}$ & $10 \mathrm{~m}^{2}(6.2 \%)$ & $54 \mathrm{~m}^{2}(11.5 \%)$ & $19 \mathrm{~m}^{2}(5.4 \%)$ \\
\hline Inflow of water & $\begin{array}{l}\text { Direct runoff, } \\
\text { small opening } \\
(15 \mathrm{~cm})\end{array}$ & Direct runoff & $\begin{array}{l}\text { Multiple lateral } \\
\text { openings }\end{array}$ \\
\hline $\begin{array}{l}\text { Superficial } \\
\text { outlet }\end{array}$ & None & $\begin{array}{l}\text { Elevated grid } \\
\text { ( } 25 \mathrm{~cm} \text { above the } \\
\text { ground) }\end{array}$ & $\begin{array}{l}\text { Elevated grid } \\
(25 \mathrm{~cm} \text { above the } \\
\text { ground) }\end{array}$ \\
\hline Operating time & 14 years & 10 years & 10 years \\
\hline Vegetation & Herbaceous plants & Grass & Herbaceous plants \\
\hline $\begin{array}{l}\text { Soil texture }(0- \\
10 \mathrm{~cm})\end{array}$ & Silt loam & Sandy loam & Loam \\
\hline $\begin{array}{l}\text { Bulk density (0- } \\
5 \mathrm{~cm})\end{array}$ & $1.2 \mathrm{~kg} / \mathrm{dm}^{3}$ & $1.3 \mathrm{~kg} / \mathrm{dm}^{3}$ & $1.2 \mathrm{~kg} / \mathrm{dm}^{3}$ \\
\hline
\end{tabular}

In the case of swales, this value corresponds to the area of the sampled section during the preliminary field campaign. The number in brackets indicates the infiltration/drainage area ratio.

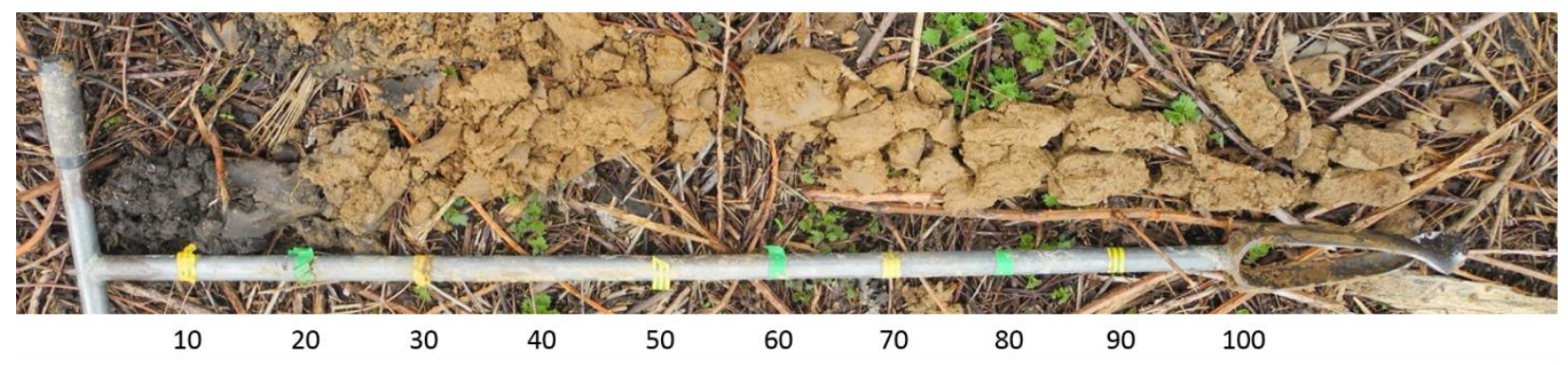

Figure 1. Soil core collected in the study site Dourdan: evidence of a dark horizon at the soil surface. Depths are given in centimeters starting from the surface.

\subsection{Selection of the sampling locations}

Preliminary investigations were undertaken between April 2015 and February 2016, in order to characterize the spatial variability of metal concentrations in the surface soil of the seven study sites (Tedoldi et al., 2017). In each site, a rectangular sampling grid was defined, considering the strictest of these two criteria: (i) collect $\geq 20$ soil samples per device, and (ii) collect $\geq 35$ samples $/ 100 \mathrm{~m}^{2}$. The upper $2-3 \mathrm{~cm}$ of soil were sampled at each node of the grid, then the $\mathrm{Cu}, \mathrm{Pb}$, 
and $\mathrm{Zn}$ contents were analyzed by X-ray fluorescence spectrometry on dried, sieved, and homogenized samples. So as to select the coring locations, cartographies of surface contamination were generated after interpolating the concentrations with universal kriging. According to the size of the facility and the range of measured concentrations, two or three homogeneous zones were defined as the regions where the $\mathrm{Cu}, \mathrm{Pb}$ and $\mathrm{Zn}$ concentrations were $(i)$ lower than the $1^{\text {st }}$ decile (Reference), (ii) higher than the $9^{\text {th }}$ decile (Zone I), and contingently (iii) ranging between the $6^{\text {th }}$ and $7^{\text {th }}$ deciles of the measurements (Zone II).

\subsection{Sampling procedure}

The coring phases were carried out between December 2015 and May 2016. In each previously defined zone, four core samples were collected with a stainless steel gouge auger $(3 \mathrm{~cm}$ inner diameter) which was cleaned and rinsed twice with ultrapure water between two samplings. The maximum depth of investigation was variable from one site to another: it was set to $40 \mathrm{~cm}$ in the least contaminated facilities at the soil surface (Sausset1, Sausset2), and up to $80 \mathrm{~cm}$ in the most contaminated ones. However, in Chanteraines and Alfortville, such depths could not be reached due to the presence of the road sub-base, and the aforementioned clay horizon, respectively. The core samples were subdivided into six to nine depth sections, whose thicknesses $(2.5-20 \mathrm{~cm})$ were chosen to include the distinguishable transitions between two soil horizons, and to have a higher resolution near the surface: the upper $15 \mathrm{~cm}$ were divided into 3 to 5 segments whatever the site. For each depth, a bulk sample ( $250 \mathrm{~g}$ ) was composited from the four corresponding subsamples (Figure 2). Whenever present, additional samples of raw sediment were collected on the nearby road pavement; such deposits could not be found in the immediate vicinity of Sausset and Alfortville. The samples were filled in individual polyethylene bags, stored in the dark at $4 \pm 1^{\circ} \mathrm{C}$ at the end of the field campaign, then sent for analysis to a laboratory with COFRAC (French Accreditation Committee) certification. 


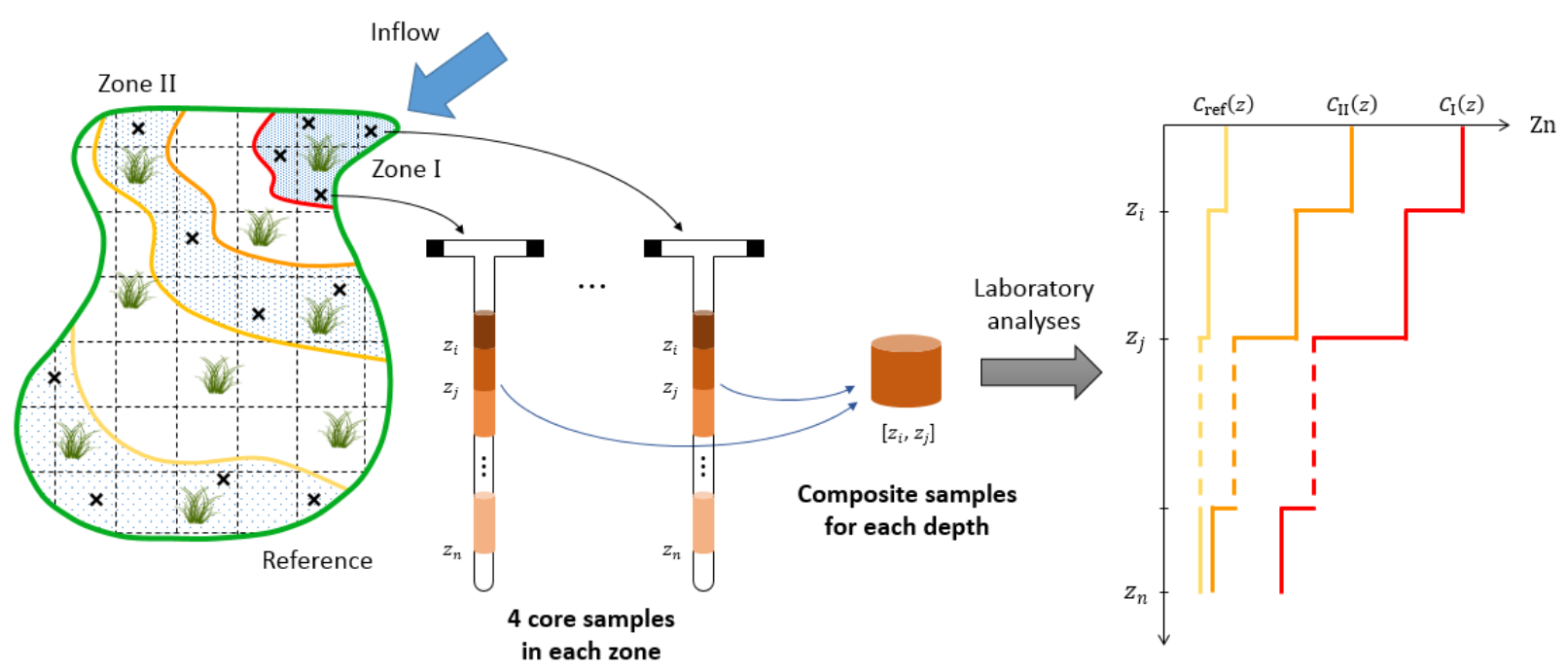

Figure 2. Schematic representation of the global methodology for soil sampling and analysis

\subsection{Laboratory analyses}

Physicochemical analyses cover a wide range of contaminants and soil parameters: 8 metals $(\mathrm{Cu}, \mathrm{Pb}, \mathrm{Zn}, \mathrm{Cd}, \mathrm{Cr}, \mathrm{Ni}, \mathrm{Co}, \mathrm{Mo}), 16 \mathrm{PAH}$ classified as priority pollutants by the US-EPA, $\mathrm{pH}_{\text {water, }}$ cation exchange capacity (CEC), volatile matter, and total carbonates. $\mathrm{Cu}, \mathrm{Pb}$ and $\mathrm{Zn}$ are chronically associated to the urban- and traffic-derived contamination and ubiquitously encountered in runoff, so is Cd in lower concentrations (Gromaire-Mertz et al., 1999; Huber et al., 2016; Kayhanian et al., 2012). Cr and Ni are largely employed in urban environments, especially for vehicle manufacturing, but their occurrence in urban stormwater runoff has been less documented (Göbel et al., 2007) and they are hardly ever analyzed in SUDS soil (Tedoldi et al., 2016). Very little data is available regarding Co and Mo in both environments (Ferreira et al., 2013), although Morrow et al. (2010) showed that PVC pipes may be a source of molybdenum for water. Among the 16 investigated PAH, Benzo[a]anthracene, Chrysene, Benzo[b]fluoranthene, Benzo[k]fluoranthene, Benzo[a]pyrene, Dibenz[ah]anthracene, and Indeno[1,2,3-cd]pyrene are suspected to be carcinogenic for humans (US-EPA, 1999). As regards pedological parameters, CEC expresses the total charge of exchangeable cations that $1 \mathrm{~kg}$ of dry soil is capable of holding (Sposito, 2008). Volatile matter constitutes a widely used estimation of soil organic matter (Gobat et al., 2013). Metal carbonates $\left(\mathrm{CuCO}_{3}, \mathrm{PbCO}_{3}\right.$, etc.) may precipitate in calcareous soils (Martinez and Motto, 2000), showing the potential role of carbonates in metal retention. 
The soil samples were pre-treated (ISO 11464, 2006) and divided into representative subsamples on which to perform the different analyses. Total metal concentrations were determined after acid digestion $\left(\mathrm{HF}+\mathrm{HClO}_{4}\right)$, according to the standard NF X31-147 (1996); Cu, Zn, Cr, Ni, and Co were analyzed by ICP-AES (ISO 22036, 2009), and Pb, Cd, and Mo were analyzed by ICP-MS (ISO 17294-2, 2016). The samples originating from the most contaminated zone of each site also underwent a metal extraction with $0.01 \mathrm{M} \mathrm{CaCl}_{2}$, followed by ICP-MS analysis, in order to evaluate the metals' easily exchangeable fraction and bioavailability for plants (Novozamsky et al., 1993). PAH were extracted via Accelerated Solvent Extraction with a mixture of acetone, hexane and dichloromethane, then detected by HPLC (XP X33-012, 2000). All contaminant concentrations are given in milligrams per kilogram of dry matter. The limits of quantification (LoQ) are provided as Supplementary data. Total metal concentrations were never $<$ LoQ; whenever the situation occurred for a $\mathrm{PAH}$, this compound was assigned $\mathrm{LoQ} / 2$ for the calculation of $\sum$ PAH. Analytical uncertainties (also presented as Supplementary data) were provided by the laboratory as a $95 \%$ confidence interval derived from both intra- and inter-laboratory repeatability and reproducibility studies.

Soil $\mathrm{pH}$ was determined in a solution of soil and ultrapure water (volumetric ratio of 1:5) after $1 \mathrm{~h}$ of equilibration (ISO 10390, 2005). So as to determine CEC, the soil samples were saturated with ammonium cations $(1 \mathrm{M})$, which were subsequently released by ion exchange with a $\mathrm{NaCl}$ solution (1 M) and detected by spectrocolorimetry (NF X31-130, 1999). A fraction ( 10 g) of each sample was calcined at $550^{\circ} \mathrm{C}$ for 6 hours, so as to determine its volatile matter content from mass difference. The carbonate content was determined by adding hydrochloric acid (4 M) to decompose any carbonates present, and measuring the volume of $\mathrm{CO}_{2}$ produced with a Scheibler apparatus (ISO 10693, 2014).

\subsection{Data handling}

Profiles. The classical way to represent the acquired data is to consider the vertical evolution of the metal and PAH concentrations, and pedological parameters, in the two or three zones of each device, as schematized on Figure 2. PAH contamination is often appraised via aggregates, adding the concentrations of each individual compound (Tedoldi et al., 2016); however, their distribution patterns (i.e. their respective contribution to $\sum \mathrm{PAH}$ ) will also be highlighted in the present paper. 
Statistical analyses. In addition to contamination profiles, statistical analyses were performed so as to identify similarities between soil samples and correlations between variables. Twovariable correlations were assessed via Pearson's coefficient $r$, defined as:

$$
r_{X Y}=\frac{\operatorname{cov}(X, Y)}{\sigma_{X} \sigma_{Y}}
$$

where cov denotes the covariance between two variables, and $\sigma_{X}$ and $\sigma_{Y}$ are the standard deviations of $X$ and $Y$. The subsequent results and discussion will also refer to the associated test of significance and $\mathrm{p}$-value (the null hypothesis being $\left\{r_{X Y}=0\right\}$, i.e. absence of correlation between $X$ and $Y$ ). Multivariate analysis was carried out through (i) Principal Component Analysis (PCA), and (ii) Hierarchical Cluster Analysis (HCA), on the normalized values (Z-scores), i.e.:

$$
Z=\frac{X-\mu_{X}}{\sigma_{X}}
$$

where $\mu_{X}$ is the mean value of the variable $X$ in the entire set (i.e. including all study sites). Euclidean distance was used as a measure of the dissimilarity between two samples. Ward's method was used as an agglomeration criterion for the HCA. Only the five predominant PAH were retained (as presented below), so as to avoid biases related to the compounds $<$ LoQ. The whole analysis was performed using R software.

\section{RESULTS}

\subsection{Distribution of metals in the surface soil}

Overall, the seven study sites could be classified as follows with respect to $\mathrm{Cu}$ and $\mathrm{Zn}$ surface contamination: Alfortville $>$ Dourdan $\gtrsim$ Greffiere $>$ Vitry $>$ Sausset, Chanteraines. The order was somewhat different for $\mathrm{Pb}$, whose highest contents were measured in Alfortville, Dourdan, and Vitry with comparable levels. As regards the metals' distribution within each site, Figure 3 displays typical examples of contamination cartographies, with the case of $\mathrm{Zn}$ in Sausset1 and Chanteraines. Whatever the device, concentrations were found to be spatially structured with respect to the inflow area: this characteristic feature included a significant accumulation near the water inlet, from which concentrations markedly decreased with increasing distance. These observations, the implications of which have been thoroughly discussed elsewhere (Tedoldi et al., 
2017), give a time-integrated vision of the non-uniform infiltration fluxes and sedimentation processes within an infiltration device.

Notably, in the case of longitudinal swales with supposedly homogeneous and diffuse inflow of water along the pavement (Chanteraines, Vitry), important disparities in the surface flow pathways could be evidenced in this manner (Figure 3.b). The latter were due to local, barely detectable differences in topography, which either concentrated road runoff in a hollow before entering the device (e.g. at $y=4 \mathrm{~m}$ on Figure $3 \mathrm{~b}$ ), or deviated it right or left from a small mound. This observation demonstrates that an "intuitive" method for the selection of the coring points, based on the distance from the road, could have led to biased composite samples. The adopted two-phase sampling procedure thus appeared as an efficient way to enhance the representativeness of the contamination profiles.

(a)

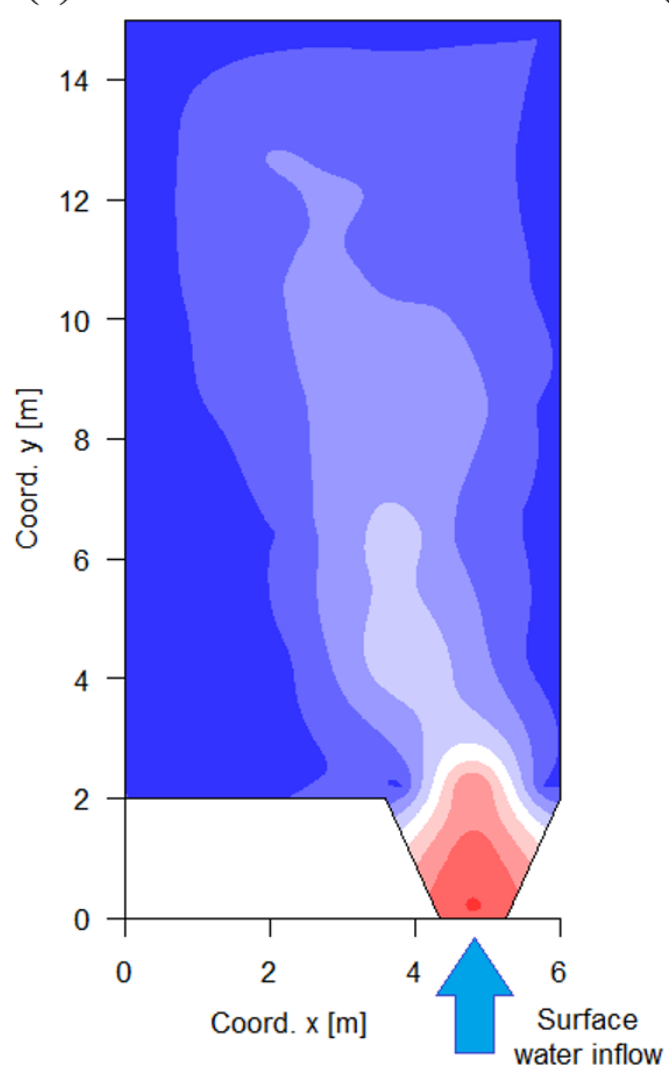

(b)

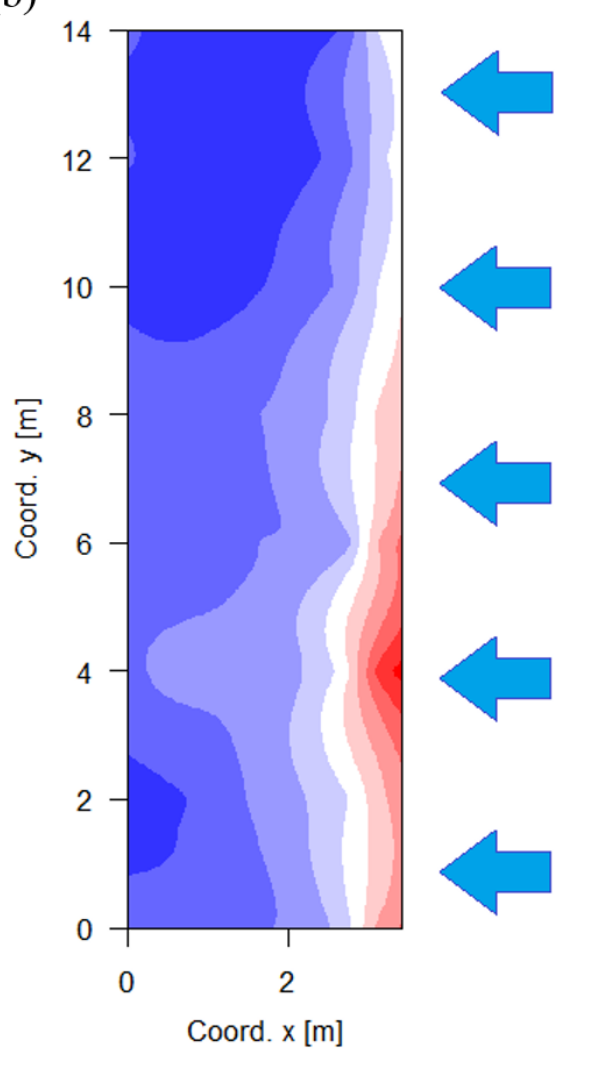

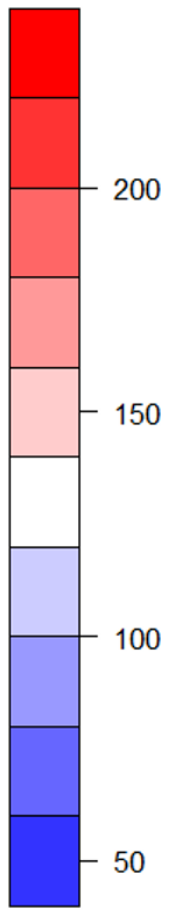

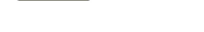

Figure 3. Spatial distribution of zinc $[\mathrm{mg} / \mathrm{kg}]$ in the surface soil of the sites (a) Sausset 1 and (b) Chanteraines (top view). The blue arrows indicate the water inflow. 


\subsection{Pedological parameters}

The seven study sites covered a wide range of soil textures allowing for water infiltration (Table 1). The particle size distribution appeared to be fairly stable along the soil profiles. The facilities with lowest clay fractions were Sausset1 and 2 (5-7\%), Chanteraines (12-14\%), and Dourdan (12-16\%). The soil of every study site was neutral to alkaline; soil pH was lower at the surface, possibly because of biological and plant activity (Gobat et al., 2013), and increased with increasing depth until it reached a plateau around $\mathrm{pH}$ 8-8.5 (Figure 4).

Conversely, volatile mater contents displayed a clear decrease with increasing depth, and followed the sequence Zone I > (Zone II) > Reference over the entire soil profiles, except in Vitry. This observation might be due to the deposition and filtration of organic-rich suspended solids near the inflow area, and/or enhanced humus production in the most frequently flooded zone, thus forming the variably thick dark upper horizon observed in most facilities (Figure 1). So as to identify the contribution of both processes, it should be noticed that the upper horizon of Dourdan, Greffiere, and Alfortville - where native vegetation is allowed to grow with a limited number of cleaning operations - had high volatile mater contents (20-25\%); conversely, the range of values found in the sediment samples collected on the road pavement was lesser (7-14\%), indicating that the formation of the upper horizon is not entirely attributable to sedimentation. The remaining four facilities had lower levels of volatile matter at the surface (10-14\% in Sausset1 and 2, and 6-9\% in Chanteraines and Vitry). Below 30-40 cm, the soil of all sites displayed volatile matter contents between 3 and $6 \%$.

CEC ranged from 5.3 to $31.6 \mathrm{cmol}+/ \mathrm{kg}$ with a median value of $13.4 \mathrm{cmol}+/ \mathrm{kg}$. The sites with lowest CEC were Chanteraines $\left(6.5-12.4 \mathrm{cmol}_{+} / \mathrm{kg}\right)$, Vitry $\left(8.2-13.7 \mathrm{cmol}_{+} / \mathrm{kg}\right)$, and Dourdan in the reference zone $\left(5.3-8.6 \mathrm{cmol}_{+} / \mathrm{kg}\right)$. Conversely, the highest values were measured in Greffiere $\left(10.5-31.6 \mathrm{cmol}_{+} / \mathrm{kg}\right)$ and Alfortville $\left(15.1-27.2 \mathrm{cmol}_{+} / \mathrm{kg}\right)$. In the largest infiltration basins (Dourdan, Greffiere, Alfortville, Sausset1), CEC clearly co-fluctuated with volatile matter: Pearson's correlation coefficient $r$ respectively equaled 0.99, 0.94, 0.94, and 0.92 (which is statistically significant with $p<10^{-4}$ ). As discussed by Boivin et al. (2008), this probably indicates that soil organic matter generates most of the CEC. In Chanteraines and Vitry, this trend was not as clear as in the above-mentioned examples: since both sites have lower contents of volatile 
matter, CEC may be partially attributed to other soil constituents such as clays (Gobat et al., 2013). Total carbonates showed high dispersion within each site and often erratic trends.

The soil of Chanteraines and Vitry exhibited a peculiar behavior: abrupt shifts in all pedological parameters could be observed in one or two sampling zone(s), but not in the entire swales, and these transitions were found at different depths within the same device (see Supplementary data). This suggested the presence of significant soil heterogeneities, which may be related to the use of different construction materials, or to the underlying substratum, as both swales were made of exogenous soil.

\subsection{Metal profiles}

Figure 4 presents contaminant concentrations as a function of depth, in each homogeneous zone of the Greffiere infiltration basin. $\mathrm{Zn}$ and $\mathrm{Cu}$ profiles obtained in the other six study sites are displayed on Figure 5.a-b, and additional examples are provided as Supplementary data. As a reminder, the two or three sampling zones were defined in regards to the $\mathrm{Cu}, \mathrm{Pb}$ and $\mathrm{Zn}$ distribution in the surface soil, so that their concentrations follow the order Zone I $>$ (Zone II) $>$ Reference. In all sites except Vitry, this sequence was the same over the whole soil profile, showing that metal accumulation did not occur only at the surface. Reference profiles of $\mathrm{Cu}, \mathrm{Pb}$, and $\mathrm{Zn}$ were fairly uniform (at least below $5 \mathrm{~cm}$ ), confirming that this zone was marginally influenced by stormwater infiltration, so that concentrations could actually be considered as the geochemical background. Contrariwise, in Vitry, initial concentrations in the topsoil, available thanks to technical studies carried out after the construction works and indicated on Figure 5.a-b with a star, demonstrate that a non-negligible metal buildup also occurred in the reference zone, probably through atmospheric fallout and water splashing.

In Zones I and II, concentrations commonly decreased with increasing depth, thus coming close to the reference values. For example, in the most polluted zone of Greffiere (Figure 4), surface concentrations amounted to $148 \pm 7,121 \pm 8$, and $812 \pm 38 \mathrm{mg} / \mathrm{kg}$ for $\mathrm{Cu}, \mathrm{Pb}$, and $\mathrm{Zn}$, respectively, and the maximum vertical gradients were 10,7 , and $53 \mathrm{mg} / \mathrm{kg} / \mathrm{cm}$. As a result, metal contents were divided by 3.5 to 5.5 within $20 \mathrm{~cm}$, and they were comparable in the three zones below $60 \mathrm{~cm}$. This decreasing trend confirms the conclusions of most previous assessments (Dechesne et al., 2004; Li and Davis, 2008; Winiarski et al., 2006). In general, the shape of metal profiles appeared to depend on the age of the facility: older devices such as the seven study sites generally showed 
uniform profiles and deeper contamination (Barraud et al., 2005; Mikkelsen et al., 1996; Norrström and Jacks, 1998), whereas in the most recent systems (a few years of operation), metal retention was restricted to the upper horizon, so that reference contents were reached within $\leq 15 \mathrm{~cm}$ (Jones and Davis, 2013; Paus et al., 2014; Schroeder, 1995).

The sites with lowest contamination potential (Sausset1, Sausset2, Chanteraines) displayed lesser surface contents in Zone I compared to the other four devices $(41-51 \mathrm{mg} / \mathrm{kg}$ for $\mathrm{Cu}, 29-$ $55 \mathrm{mg} / \mathrm{kg}$ for $\mathrm{Pb}$, and $130-161 \mathrm{mg} / \mathrm{kg}$ for $\mathrm{Zn}$ ), with a decreasing trend along the soil profiles as well; however $\mathrm{Cu}$ and $\mathrm{Zn}$ in the deepest sample were still higher than the reference values (Figure 5). Conversely, highest surface contamination was found in Alfortville and Dourdan (150$360,190-310$, and $1100-2100 \mathrm{mg} / \mathrm{kg}$ for $\mathrm{Cu}, \mathrm{Pb}$, and $\mathrm{Zn}$, respectively). In these two sites, $\mathrm{Cu}$ and $\mathrm{Pb}$ concentrations were nearly uniform over the upper $15-20 \mathrm{~cm}$ of soil, or even slightly increased with depth; considering the $95 \%$ confidence intervals deriving from the analytical uncertainties, this increase was found to be significant for $\mathrm{Pb}$ only. Despite this peculiar behavior near the surface, all metal contents ultimately reached or came close to the reference profiles below 25 to $40 \mathrm{~cm}$. In the swale Vitry, this "typical" decrease was visible in the upper $15 \mathrm{~cm}$ of soil, within which metal contents almost reached the initial values. Underneath, however, concentrations appeared to be heterogeneously distributed in space, so were most pedological parameters. This trend may have corresponded to "historical" pollution of the parent material, and was not necessarily related to stormwater infiltration.

The range of concentrations measured by Achleitner et al. (2007), Ingvertsen et al. (2012), Jones and Davis (2013), and Lind and Karro (1995), in small-scale swales or bioretention systems (10$100 \mathrm{mg} / \mathrm{kg}$ for $\mathrm{Cu}, 9-120 \mathrm{mg} / \mathrm{kg}$ for $\mathrm{Pb}, 50-400 \mathrm{mg} / \mathrm{kg}$ for $\mathrm{Zn}$ ), is comparable to the values found in Sausset and Chanteraines. Likewise, the median values derived from a literature review dedicated to soil contamination in roadside embankments were 48,106 , and $180 \mathrm{mg} / \mathrm{kg}$, respectively (Werkenthin et al., 2014). On the other hand, Barraud et al. (2005), Dechesne et al. (2004), Napier et al. (2009), and Norrström and Jacks (1998) carried out similar assessments in different infiltration basins, which were larger and more centralized than Dourdan, Greffiere, and Alfortville (infiltration area between 400 and $2000 \mathrm{~m}^{2}$, and infiltration/drainage area ratio $<0.6 \%$ ), but the metal concentrations were in the same order of magnitude: the maximum values measured in each site ranged from 180 to $260 \mathrm{mg} / \mathrm{kg}$ for $\mathrm{Cu}, 100$ to $320 \mathrm{mg} / \mathrm{kg}$ for Pb , and 780 to $2600 \mathrm{mg} / \mathrm{kg}$ for $\mathrm{Zn}$. 
The behavior of the five remaining metals could not be generalized to every study site. The spatial distribution of $\mathrm{Cd}$ and Mo was globally the same as $\mathrm{Cu}, \mathrm{Pb}$ and $\mathrm{Zn}$, except in Sausset1 and 2, even if they were detected in much lower concentrations (see Supplementary data). For Cd, the highest values found in each site ranged from $0.29 \pm 0.03 \mathrm{mg} / \mathrm{kg}$ in Chanteraines to $2.93 \pm 0.19 \mathrm{mg} / \mathrm{kg}$ in Dourdan; maximum Mo concentrations varied between $1.2 \pm 0.1 \mathrm{mg} / \mathrm{kg}$ in Chanteraines and $22.9 \pm 1.3 \mathrm{mg} / \mathrm{kg}$ in Alfortville. The vertical distribution of $\mathrm{Cr}, \mathrm{Ni}$, and Co in Dourdan and Alfortville was equally characterized by a surface buildup, followed by a decrease in concentrations with increasing depth. $\mathrm{Cr}$ accumulation could also be observed in the surface horizon of Greffiere ( $\sim 70 \mathrm{mg} / \mathrm{kg})$, even if this metal was more heterogeneously distributed below $30 \mathrm{~cm}$ (Figure 4). No particular tendency could be noticed in the rest of the cases. Alfortville's Zone I exhibited highest levels of almost all metals, with $442-1260 \mathrm{mg} / \mathrm{kg}$ for Cr, $167-452 \mathrm{mg} / \mathrm{kg}$ for $\mathrm{Ni}$, and $18-27 \mathrm{mg} / \mathrm{kg}$ for $\mathrm{Co}$, which was noticeably higher than the $3^{\text {rd }}$ quartile of the whole analyses (resp. 69, 33, and $13 \mathrm{mg} / \mathrm{kg}$ ).

It should actually be noticed that no study has reported comparable $\mathrm{Cr}$ and $\mathrm{Ni}$ concentrations to what was found in Alfortville: the maximum available values are 240 and $228 \mathrm{mg} / \mathrm{kg}$, respectively, which were measured in roadside soils (Werkenthin et al., 2014). Aryal et al. (2007) evidenced Cr and $\mathrm{Ni}$ contents of 94 and $80 \mathrm{mg} / \mathrm{kg}$, respectively, at the bottom of an infiltration soakaway. Consequently, illicit industrial connections to the storm sewer system are suspected in Alfortville. Co and Mo have not been sufficiently investigated to draw general conclusions; in a centralized infiltration basin, their concentrations were 10-17 and 2-6 mg/kg, respectively (Schroeder, 1995), whereas Aryal et al. (2007) measured Co contents of $25-33 \mathrm{mg} / \mathrm{kg}$ at the bottom of two soakaways, which in both cases corresponds to the upper range of the present results.

Concerning metals' mobility, $\mathrm{Cu}, \mathrm{Zn}$, and $\mathrm{Cd}$ were the only contaminants that could be quantified in $\mathrm{CaCl}_{2}$ leachate (along with $\mathrm{Ni}$ in Dourdan and Alfortville only). In any case, extractable concentrations represented $<0.5 \%$ of the total concentrations for $\mathrm{Cu}, \mathrm{Zn}$ and Ni, and $<1.3 \%$ for $\mathrm{Cd}$. For instance, $260 \mu \mathrm{g} \mathrm{Cu} / \mathrm{kg}$ and $1600 \mu \mathrm{g} \mathrm{Zn} / \mathrm{kg}$ could be extracted from the upper sample of Dourdan's Zone I, whereas total contents were 155 and $1100 \mathrm{mg} / \mathrm{kg}$, respectively. Likewise, in the most contaminated sample from Greffiere, extractable concentrations respectively amounted to 310 and $1300 \mu \mathrm{g} / \mathrm{kg}$ for $\mathrm{Cu}$ and $\mathrm{Zn}$, while total concentrations were 148 and $812 \mathrm{mg} / \mathrm{kg}$. The whole profiles of extractable concentrations (in Zone I only) are shown on Figure 4 for the latter device, and presented as Supplementary data for Dourdan, Alfortville, and Vitry. 
Whatever the metal, extractable contents did show a decreasing trend with increasing depth like total concentrations, except in Dourdan.

\subsection{PAH distribution patterns and profiles}

As shown on Figure 6, the distribution patterns of PAH were fairly similar from one site to another, with a few exceptions. Acenaphthene and Acenaphthylene were commonly found to be $<$ LoQ, so was Naphthalene in Greffiere, Sausset, Chanteraines, and in Dourdan's reference zone. This is consistent with the findings of Schroeder (1995), who did not detect these compounds even in the surface sample from an infiltration basin located in an industrial area. So as to avoid calculation biases, and to perform a proper inter-site comparison, Naphthalene, Acenaphthene and Acenaphthylene were not taken into account in the total PAH concentration (thereafter referred to as $\left.\sum^{13} \mathrm{PAH}\right)$. Fluorene, Anthracene, Benzo[k]fluoranthene and Dibenz[ah]anthracene could frequently be quantified in the soil samples, but remained in low concentrations, which together accounted for $\leq 15 \%$ of $\sum^{13} \mathrm{PAH}$. The five compounds detected in highest concentrations were Fluoranthene, Pyrene, Chrysene, Phenanthrene, and Benzo[b]fluoranthene, whose individual contribution to $\sum^{13} \mathrm{PAH}$ amounted to $17 \pm 3 \%, 15 \pm 2 \%, 12 \pm 3 \%, 10 \pm 3 \%$, and $9 \pm 1 \%$, respectively. Correspondingly, in previous assessments, Fluoranthene and Pyrene were often found to be the predominant compounds in both sediment and soil (Barraud et al., 2005; DiBlasi et al., 2009). Overall, there was a clear dominance of high molecular weight (HMW) compounds (i.e. PAH with $\geq 4$ aromatic rings) over low molecular weight (LMW) compounds: the average HMW/LMW ratio was 5.5. Nevertheless, the importance of LMW species was somewhat higher in Greffiere (HMW/LMW 3.4), and in the deepest samples from Chanteraines and Vitry (in the latter case, the ratio sharply decreased from $>10$ to $\sim 4$ ).

These distribution patterns in the soil of infiltration systems were mostly comparable to those of stormwater runoff from various residential areas (Figure 6). On average, the proportion of Fluorene and Phenanthrene was lower in soil than in runoff, indicating possible degradation, while the opposite trend was visible for the PAH with highest molecular weight (Dibenz[ah]anthracene, Benzo[ghi]perylene, and Indeno[1,2,3-cd]pyrene).

PAH contents displayed a noticeable inter-site variability. In decreasing order of contamination, the maximum value of $\sum^{13} \mathrm{PAH}$ was $21.7 \pm 3.1 \mathrm{mg} / \mathrm{kg}$ in Vitry, $15.7 \pm 2.1 \mathrm{mg} / \mathrm{kg}$ in Alfortville's Zone II (the values are not available in Zone I due to analytical problems), $8.6 \pm 1.2 \mathrm{mg} / \mathrm{kg}$ in 
Dourdan, $7.0 \pm 1.0 \mathrm{mg} / \mathrm{kg}$ in Chanteraines, $2.1 \pm 0.3 \mathrm{mg} / \mathrm{kg}$ in Greffiere, $0.8 \pm 0.2 \mathrm{mg} / \mathrm{kg}$ in Sausset1, and $0.6 \pm 0.2 \mathrm{mg} / \mathrm{kg}$ in Sausset 2 - which is rather different from the classification of metallic pollution but consistent with the land use. PAH contamination in the soil of infiltration systems is to a large extent attributable to industrial/incineration activities (Schroeder, 1995) or traffic density (Dierkes and Geiger, 1999). However, the watersheds of the present study sites appear to have moderate contamination potentials in comparison with the literature data. Indeed, the studies conducted by Schroeder (1995), Mikkelsen et al. (1996), and Dechesne et al. (2004), on infiltration systems located respectively in an industrial catchment, near a waste incineration plant, and near a truck parking lot, revealed much higher PAH contamination at the surface $\left(\sum^{16}\right.$ $\mathrm{PAH}=84,100$, and $>97 \mathrm{mg} / \mathrm{kg}$, respectively). Conversely, $\sum^{16} \mathrm{PAH}$ measured in roadside swales (Dierkes and Geiger, 1999; Strömvall et al., 2007), smaller infiltration basins (Napier et al., 2009), and bioretention cells (DiBlasi et al., 2009), ranged from 1 to $23 \mathrm{mg} / \mathrm{kg}$ at the surface, which is almost the same interval as the concentration range found in all facilities in the present work. Figures 4 and 5.c present $\sum^{13} \mathrm{PAH}$ as a function of depth, in each study site. PAH buildup was also limited to the upper 5 to $40 \mathrm{~cm}$, but contrary to the "usual" behavior of heavy metals, highest PAH concentrations were not systematically found in the upper sample, and the decreasing trend along the soil profile was not as obvious. This finding supports the observations of Dierkes and Geiger (1999) and Napier et al. (2009); however, it should be noticed that deep PAH transport $(>1 \mathrm{~m})$ was evidenced in several infiltration systems, and attributed to sludge migration or preferential pathways (Mikkelsen et al., 1996).

As discussed above, PAH contamination in the deepest samples from Chanteraines and Vitry was likely due to "inherited" pollution of the construction materials, which in the latter site was corroborated by a different signature of LMW compounds. Similar to the present observations, an increase in $\sum^{16} \mathrm{PAH}$ with increasing depth was observed in the equivalent "reference zone" of a bioretention system (DiBlasi et al., 2009), owing to which the authors similarly hypothesized that different materials could have been used during the facility construction. These results show that some caution should be taken when constructing infiltration systems, avoiding excavated materials from other sites which may be formerly contaminated, so as to minimize the subsequent risks of lixiviation. 

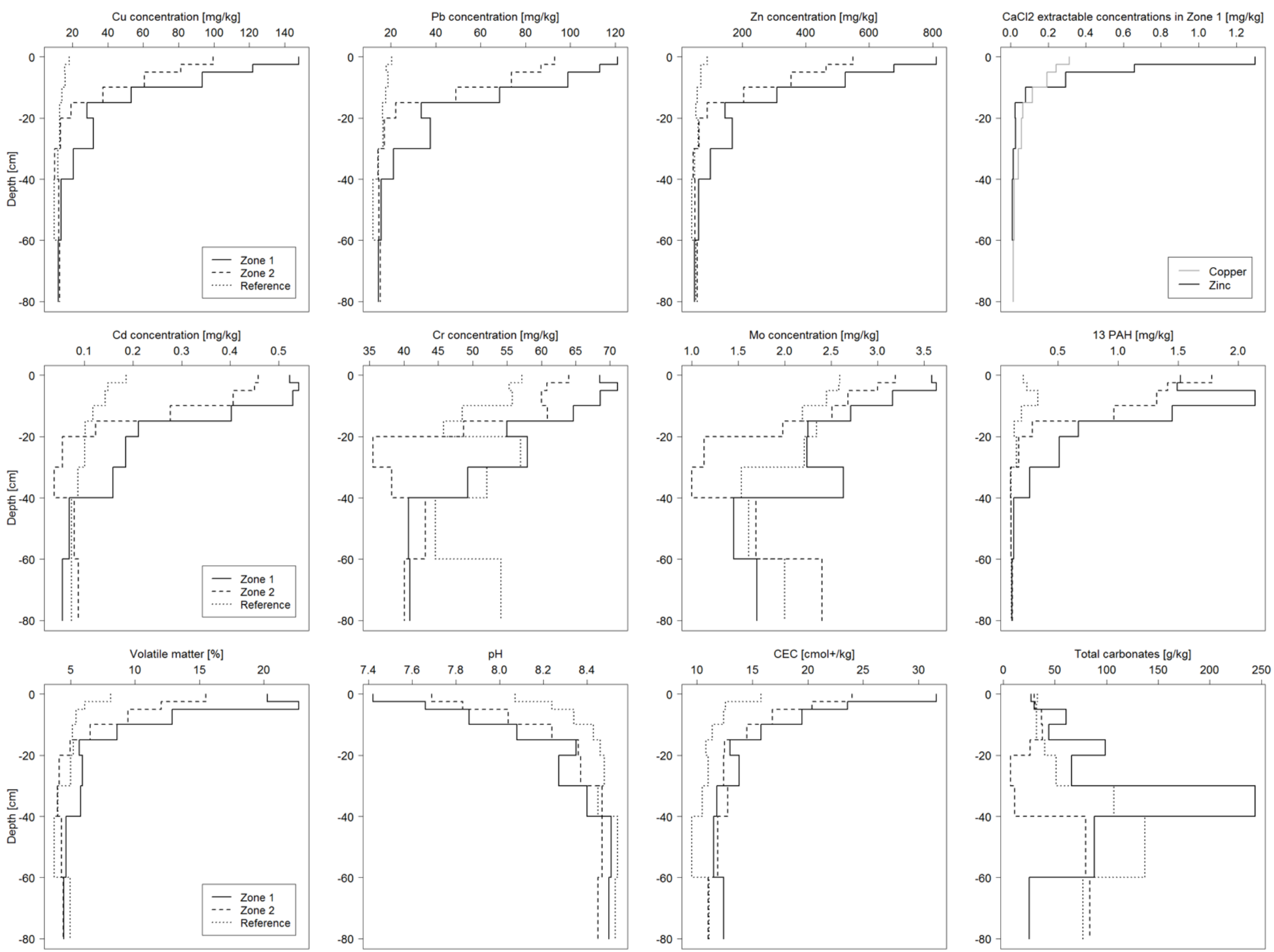

Figure 4. Complete results for the Greffiere site: vertical profiles of the contaminant concentrations and pedological parameters in each sampled zone of the basin. 


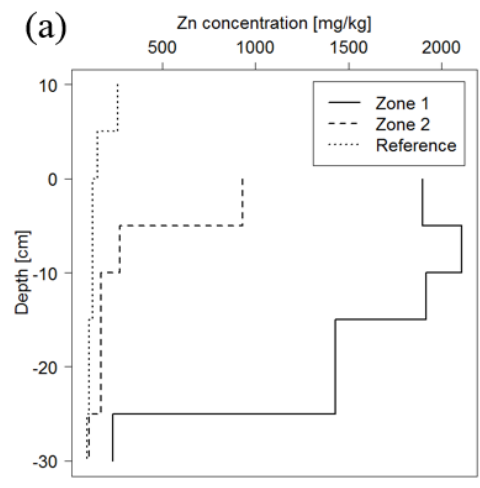

(i) Alfortville

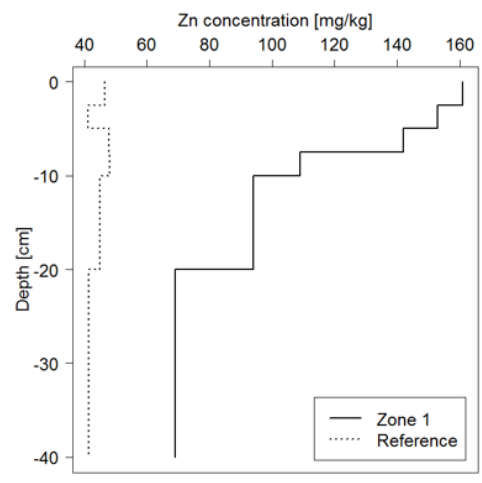

(iv) Sausset1

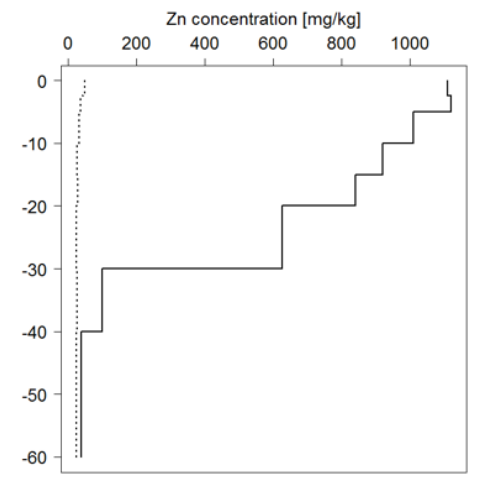

(ii) Dourdan

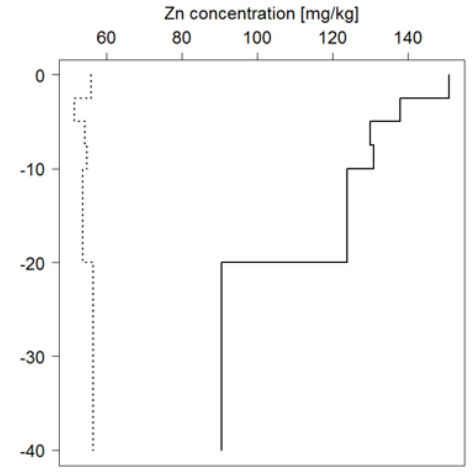

(v) Sausset 2

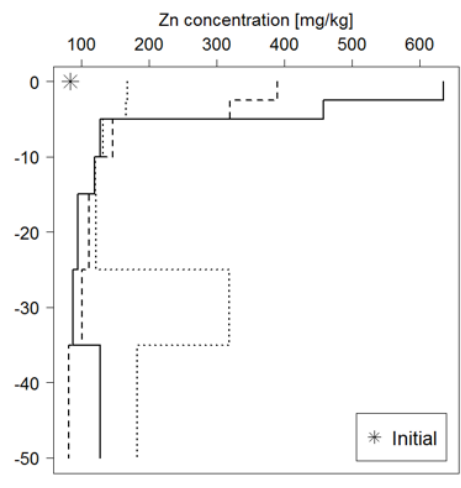

(iii) Vitry

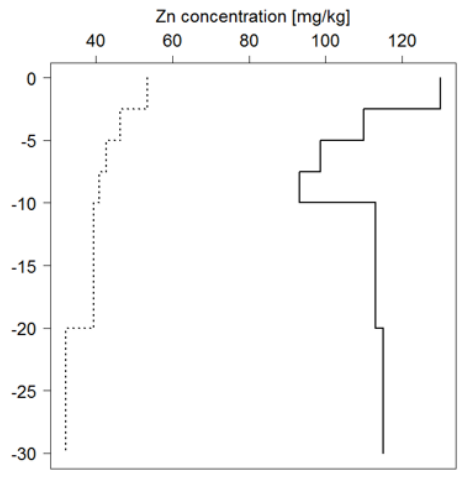

(vi) Chanteraines
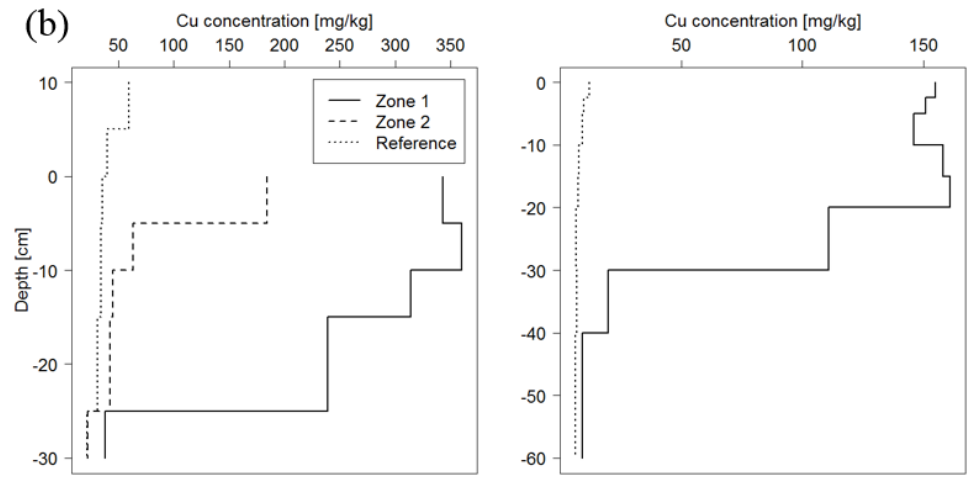

(ii) Dourdan

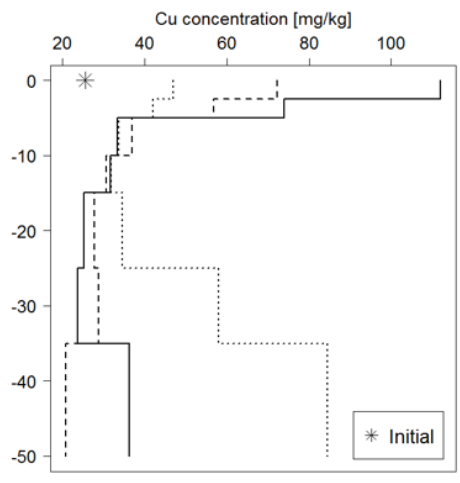

(iii) Vitry

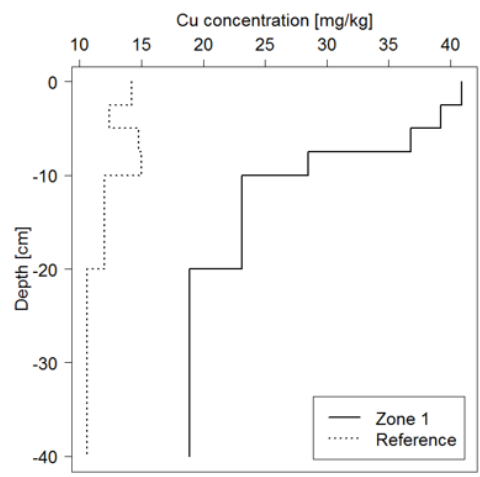

(iv) Sausset1

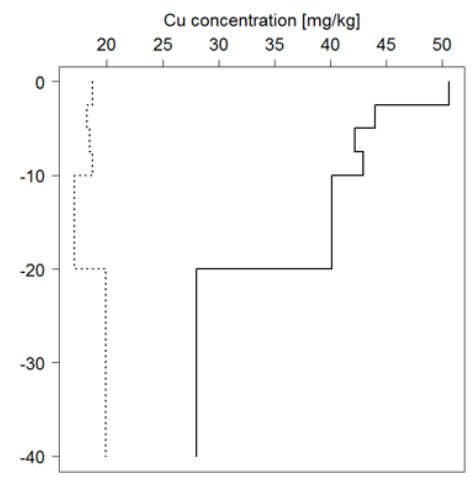

(v) Sausset2

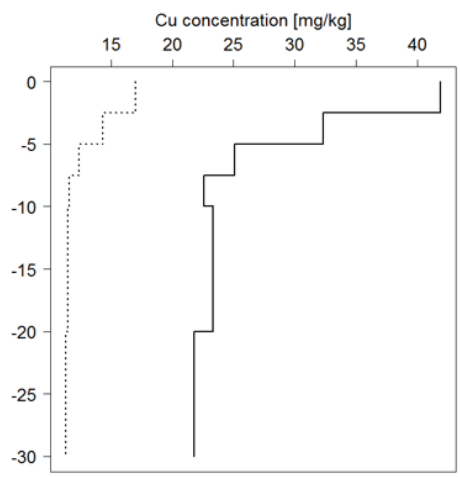

vi) Chanteraines 


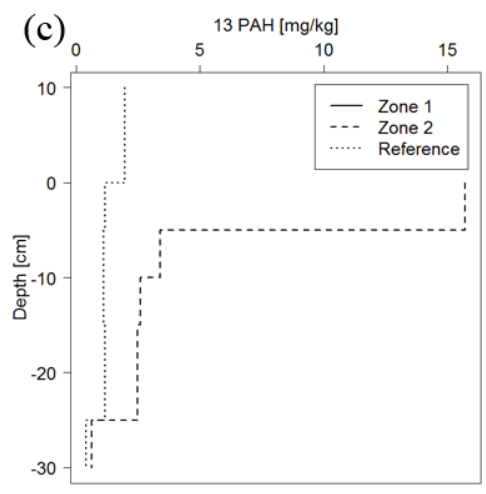

(i) Alfortville

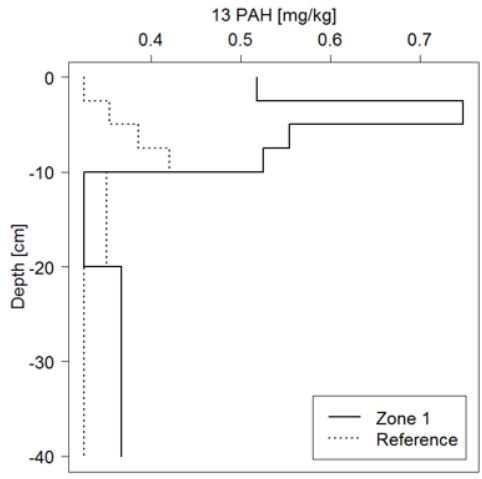

(iv) Sausset1

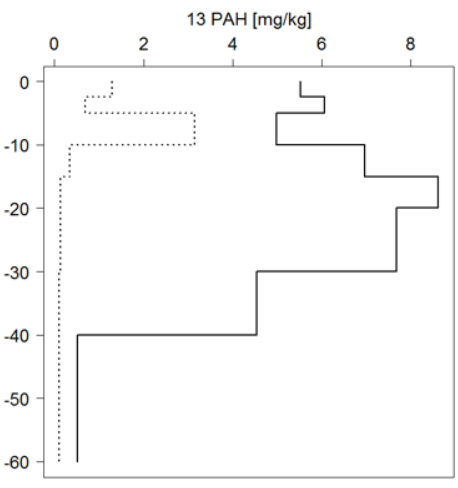

(ii) Dourdan

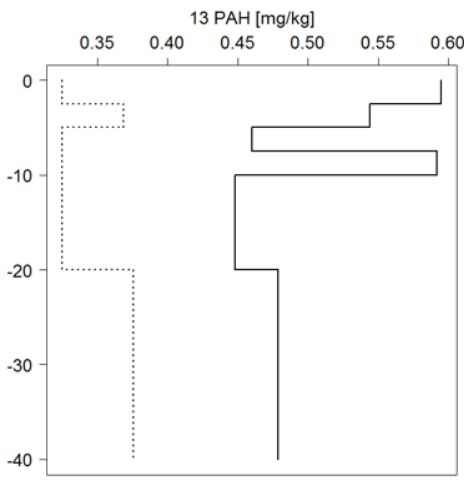

(v) Sausset 2

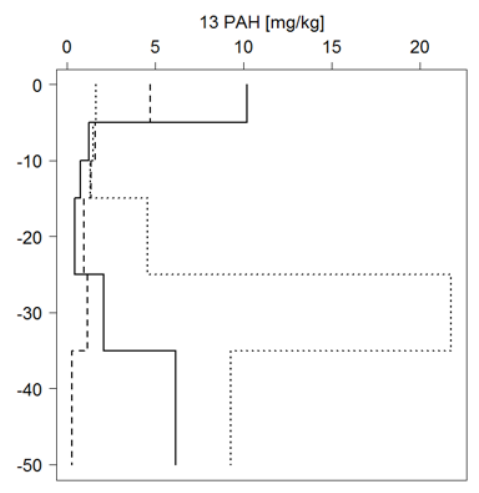

(iii) Vitry

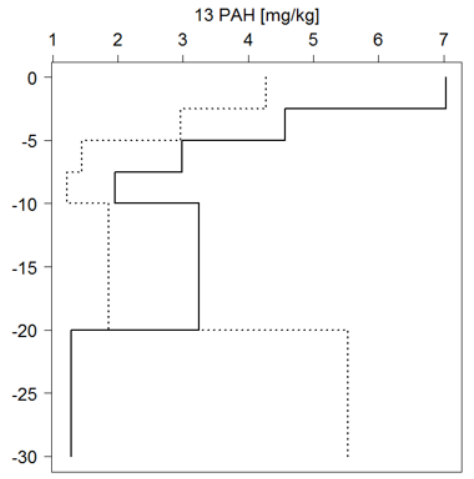

(vi) Chanteraines

Figure 5. Vertical profiles of (a) zinc, (b) copper, and (c) $\sum^{13} \mathrm{PAH}[\mathrm{mg} / \mathrm{kg}]$, in every study site. In Alfortville, the altitude $z=0$ corresponds to the bottom of the basin, and positive coordinates were assigned to the samples collected in the elevated banks (Reference zone). 


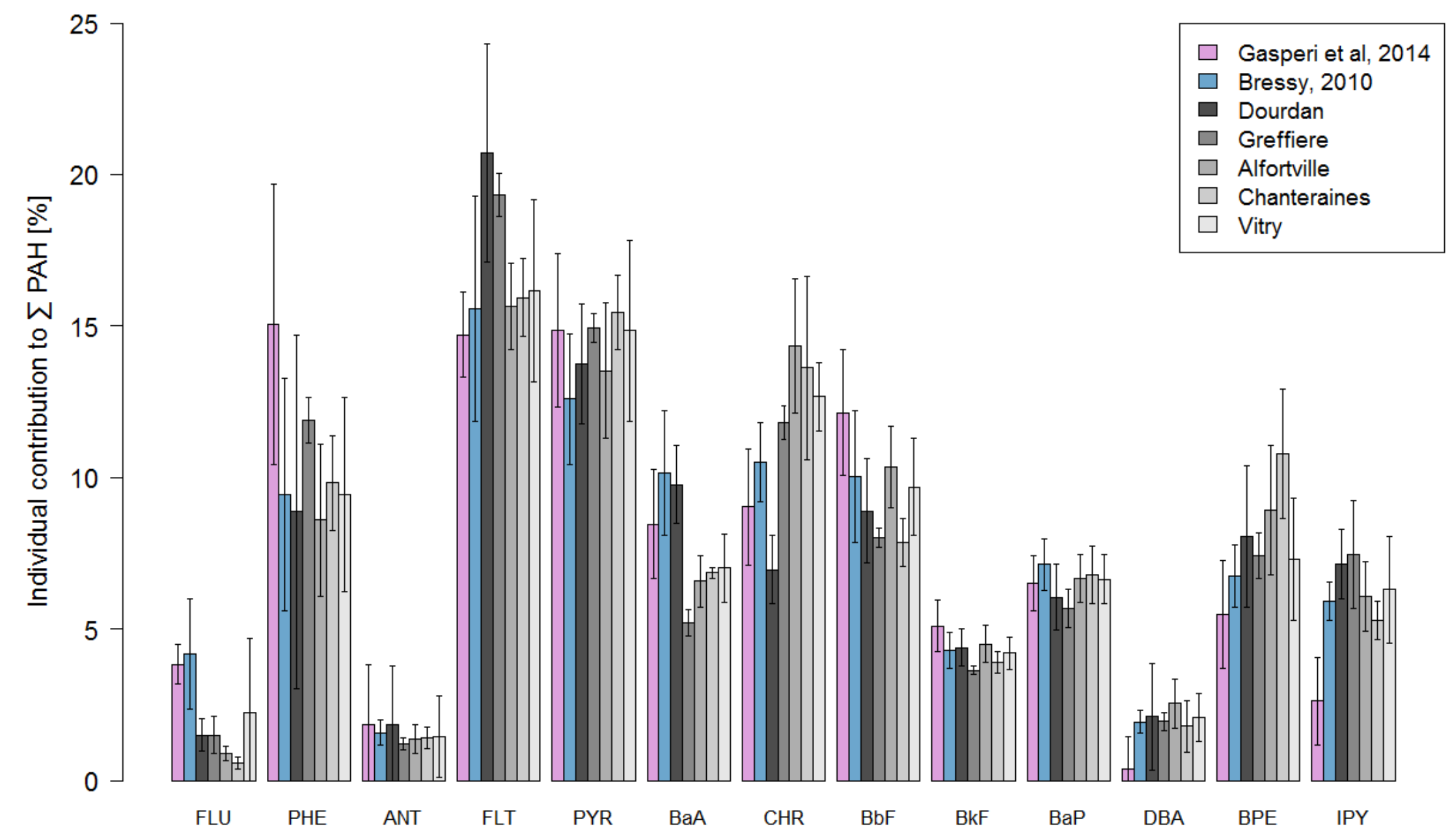

Figure 6. Individual contribution of each compound to $\sum^{13} \mathrm{PAH}[\%]$, in urban stormwater runoff from residential areas (Bressy et al., 2014; Gasperi et al., 2014), and in the soil samples of the study sites (except Sausset). 


\subsection{Statistical analysis of soil contamination}

The variables included in the present analysis comprised all pedological parameters, total metal concentrations, and the five predominant PAH (i.e. Fluoranthene, Pyrene, Chrysene, Phenanthrene, and Benzo[b]fluoranthene) to avoid biases related to the compounds $<$ LoQ. As mentioned in the section 3.4, these five compounds together amounted to more than $60 \%$ of $\sum^{13} \mathrm{PAH}$. At each branch of the dendrogram deriving from HCA (Figure 7c), the discriminating element appeared to be the contamination nature and levels. The upper samples collected in Alfortville's Zone I (group 1) were definitely dissimilar to the other ones; group 2 corresponded to samples with "mixed" pollution from Dourdan; group 3 comprised samples with mostly metallic contamination (Greffiere, Alfortville), whereas groups 4 was made of samples with high PAH contents (Vitry, Chanteraines); group 5 only included the two samples with highest PAH contamination. Two larger clusters could be distinguished in the right part of the dendrogram: reference samples from Dourdan and Chanteraines (group 6), and the rest of the samples with low to moderate contamination (group 7). The different subsets which composed the latter group were differentiated with respect to the sites and soil properties.

These seven clusters are displayed on the factorial map deriving from PCA (where the first two principal components explain $46 \%$ and $30 \%$ of the total variance, respectively) via ellipses of dispersion (Figure 7b). Two orthogonal axes are clearly distinguishable, corresponding respectively to metals and $\mathrm{PAH}$, which confirms the findings of Barraud et al. (2005). The five PAH contents were strongly correlated $\left(r>0.93\right.$, which is statistically significant with $\left.p<10^{-16}\right)$, and almost all correlations between metals could be considered significant as well ( $p<0.01$ except between $\mathrm{Cd}$ and $\mathrm{Cr}, \mathrm{Ni}$, or Mo), which was similarly reported by Werkenthin et al. (2014). This suggests common sources of contamination in the catchments. Nevertheless, both categories of contaminants appeared to be independent - except $\mathrm{Pb}$, which displayed a correlation coefficient $r \sim 0.45$ with most PAH $\left(p<10^{-6}\right)$. Metals were positively correlated to volatile matter $(r>0.60$ for all metals, and even $>0.85$ for $\mathrm{Cu}$ and $\mathrm{Zn})$ and CEC $(r>0.48)$, and in a few cases negatively correlated to $\mathrm{pH}$, but no significant tendency could be evidenced with carbonates. 
(a)

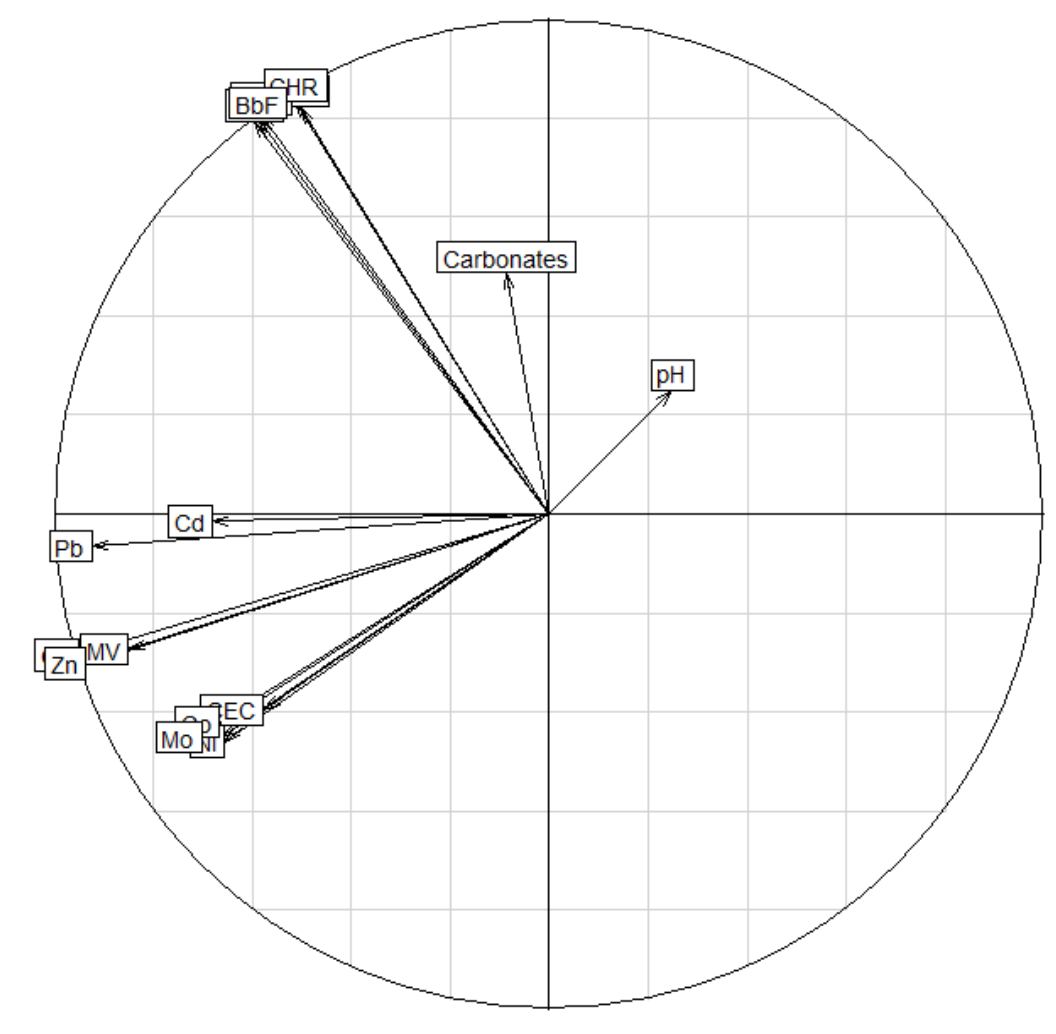

(b)

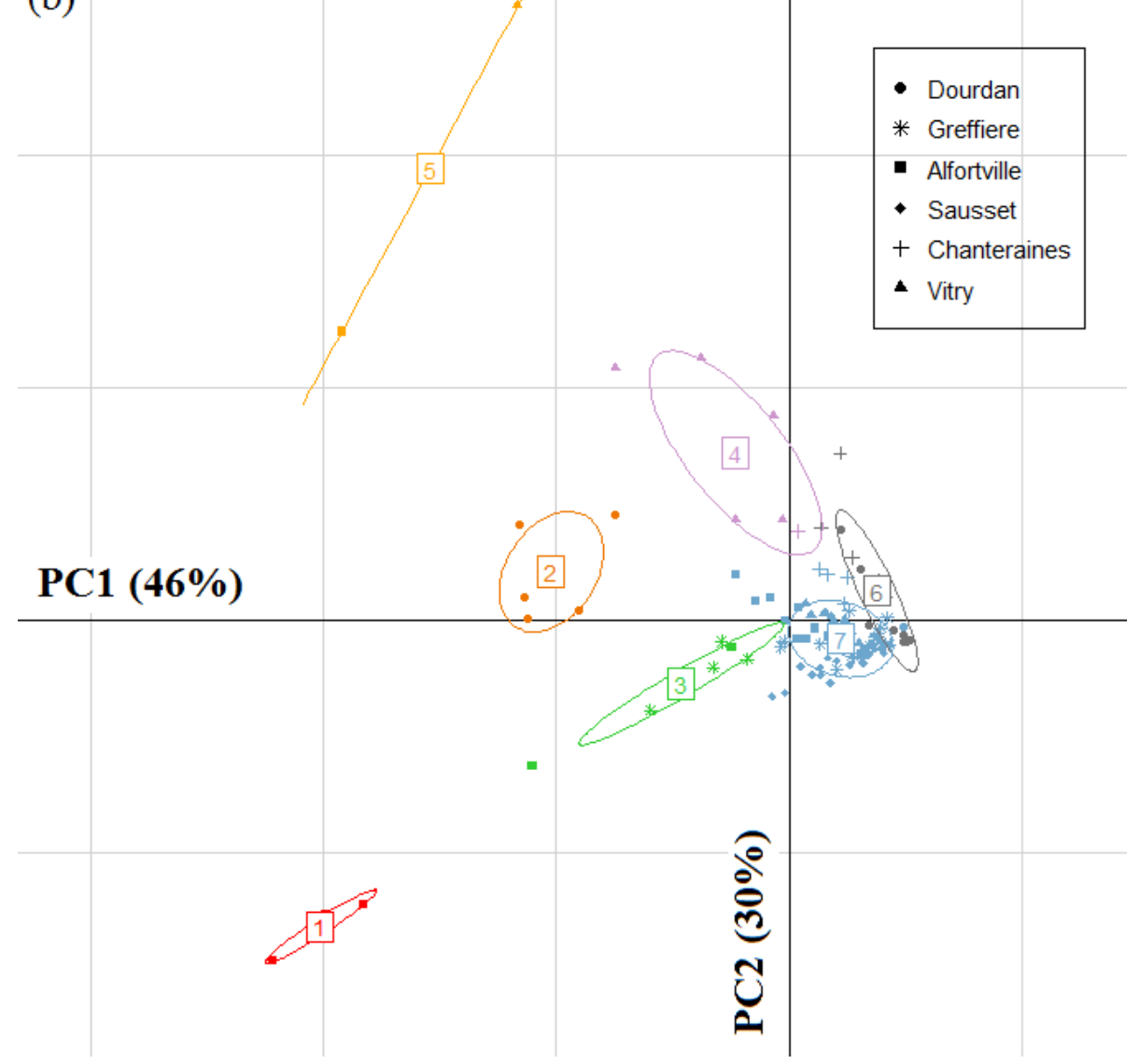


(c)

High contamination

Low to moderate contamination

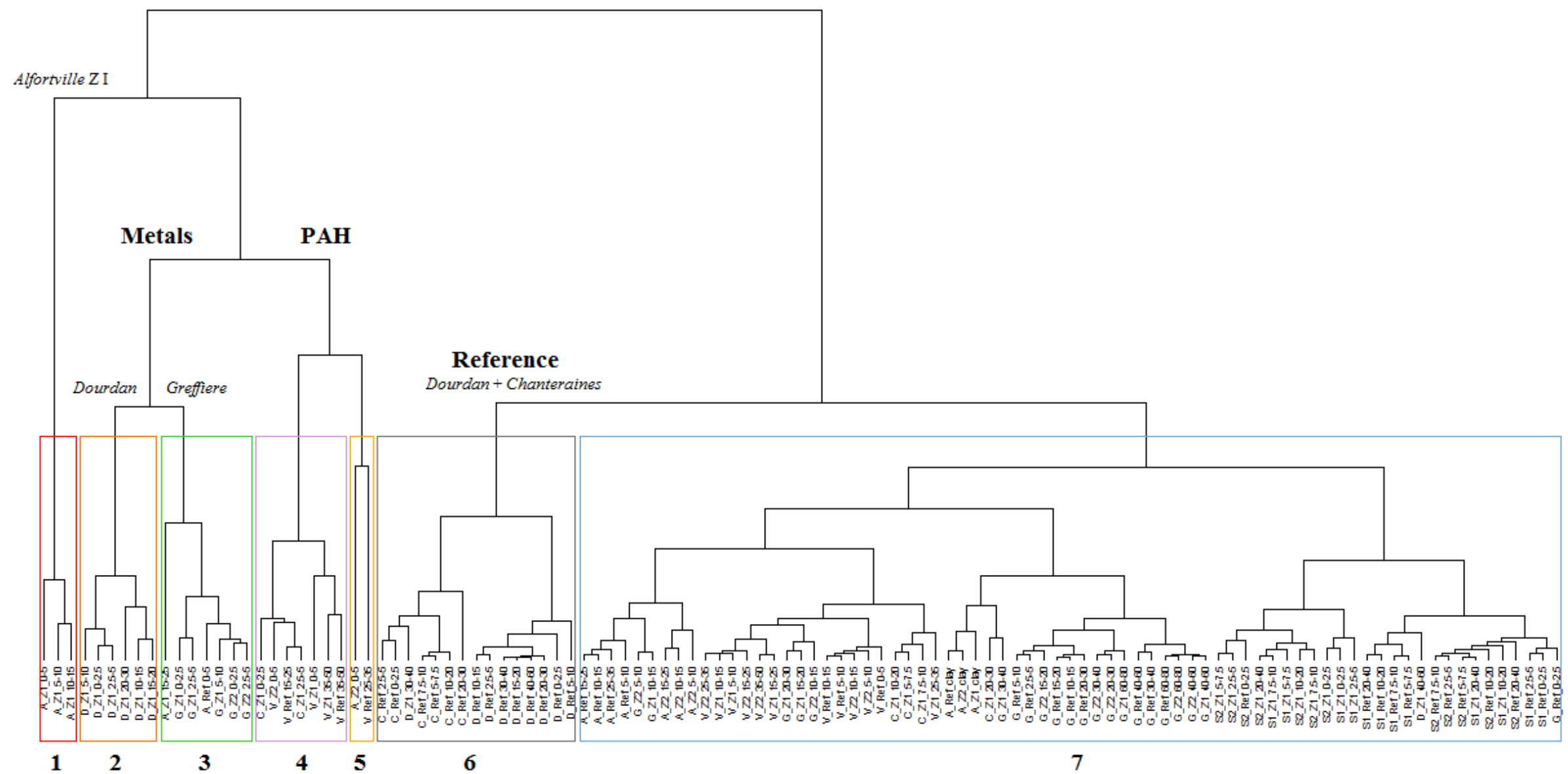

Figure 7. Multivariate analyses of the complete results: (a) correlation circle, (b) projection of the samples on the first two principal components, (c) dendrogram derived from the hierarchical cluster analysis. 


\section{DISCUSSION}

\subsection{Processes governing the vertical distribution of contaminants}

Metal retention in soils is attributable to four classes of processes: $(i)$ non-specific, charge-driven interactions with the soil matrix, (ii) coordination bonds formed with surface functional groups, (iii) precipitation, and (iv) physical filtration of particulate-bound species (Tedoldi et al., 2016). The importance of the first two categories of mechanisms can be appraised through the soil's CEC and organic matter, as confirmed by the positive correlations between these two variables and metal contents. According to the theory of equilibrium sorption, the vertical transport of reactive dissolved species results from the gradual exhaustion of the soil's sorption sites; as soon as equilibrium has been reached over the whole profile, sorbed concentrations are expected to be uniform, unless sorption capacities are variable with depth (Chrysikopoulos et al., 1990). Consequently, three interpretations - which are not mutually exclusive - may be proposed to explain the "typical" diminishing profiles evidenced in every study site: $(i)$ sorption sites may still be available in the lower horizons of soil, (ii) the retention potential of these deeper strata may be lesser than that of the surface soil, or (iii) filtered contaminants may significantly increase the upper concentrations.

The vertical evolution of volatile matter and CEC tends to support the second point. This interpretation would also be consistent with the presence of an upper horizon with dissimilar aspect (in all sites except Sausset2 and Chanteraines, $c f$. Section 2.1), the formation of which is partially attributable to enhanced organic matter production near the inflow zone. The present observations suggest that the soil's retention capacities, i.e. the maximum amount of contaminants that can be retained by a unit mass of soil, decrease with increasing depth. This is also corroborated by the findings of Paus et al. (2014), who collected samples at various depths in a biofiltration device, on which they carried out sorption experiments. Their results showed that the coefficients describing the sorption isotherm (with either Langmuir or Freundlich models) did decrease with increasing depth. In other words, in the lifetime of an infiltration device, the exhaustion of the entire soil's sorption capacities may occur sooner than expected if one only considers the retention potential of the surface horizon - after which the incoming contaminant fluxes could not be intercepted optimally, especially the dissolved fraction. Moreover, low concentrations in soil do not necessarily indicate an absence of downward pollutant fluxes, as illustrated by the three sites Sausset1, Sausset2, and Chanteraines: despite notably lower concentrations than in every other 
device, $\mathrm{Cu}$ and $\mathrm{Zn}$ reference contents have not been reached within the maximum sampling depth (Figure 5.a-b).

The contribution of filtration is expected to vary according to the metals' speciation in runoff, which actually depends on the watershed characteristics. Morrison et al. (1990), who collected stormwater samples in several urban catchments, showed that the major part of $\mathrm{Zn}$ and $\mathrm{Cd}$ was free or weakly complexed in dissolved form, whereas $>85 \%$ of $\mathrm{Pb}$ was adsorbed to suspended solids; although the highest fraction of $\mathrm{Cu}$ was also in dissolved form, a non-negligible part was associated with organic matter $(15 \%)$ or sedimentary carbonates $(\sim 20 \%)$. Solute fractions are globally higher in roof runoff (Greffiere) than in road runoff (Dourdan, Chanteraines), as shown in previous studies (Gromaire-Mertz et al., 1999; Huber et al., 2016): this might explain the dissimilarities between $\mathrm{Cu}, \mathrm{Pb}$, and $\mathrm{Zn}$ profiles in the latter two sites, while they are alike in the former one (Figures 4 and 5.a-b). In Vitry, the sharp decrease in concentrations over the upper $5 \mathrm{~cm}$, as well as the CEC, carbonate content, and visual aspect of the surface layer, suggest probable occurrence of cake filtration. The fact that reference concentrations were noticeably higher than the initial values may be the consequence of atmospheric fallout from the industrial watershed or water splashing; it may also indicate that water spreading over the whole soil surface is more frequent in this small swale than in the other devices.

Similar to $\mathrm{Pb}, \mathrm{PAH}$ (and especially high-molecular-weight compounds) are known to be mostly in particulate form in runoff (DiBlasi et al., 2009), as a result of which their concentration profiles are generally hypothesized to be the consequence of mechanical filtration occurring in the upper 5-10 cm of soil (Barraud et al., 2005; Dechesne et al., 2004). This may be the reason why Pb was the only metal to be correlated with PAH, as presented in Section 3.5. The absence of correlation with other metals (Figure 7a) may result from dissimilar retention mechanisms but also from different sources in the watersheds. For instance, the swale Chanteraines displays moderate metal contamination (e.g. $\mathrm{Zn} \leq 130 \mathrm{mg} / \mathrm{kg}$ ) but comparatively high PAH levels $\left(\sum^{13} \mathrm{PAH}=7.0 \mathrm{mg} / \mathrm{kg}\right.$ at the surface), which is attributable to the truck traffic in the adjacent road. Conversely, the basin Greffiere is the $3^{\text {rd }}$ most contaminated site as regards metals $(\mathrm{Zn} \geq 800 \mathrm{mg} / \mathrm{kg})$, but the $5^{\text {th }}$ one with respect to PAH contamination $\left(\sum^{13} \mathrm{PAH} \leq 2.1 \mathrm{mg} / \mathrm{kg}\right)$, as the major sources of pollution are linked to metallic building materials (rooftops, valleys, and gutters) in this residential area.

In addition to filtration and sorption onto organic substances, PAH may undergo nonconservative processes such as photo- and biodegradation, especially in the biologically active 
zone (i.e. near the surface): this may explain why highest PAH contents were not systematically measured in the upper samples, in the present work (Figures 4 and 5.c) as well as in previous assessments ( $c f$. Section 3.4). LMW compounds (notably Naphthalene, Acenaphthene, and Acenaphthylene) are more volatile and easily degradable than the other PAH (Cousins et al., 1999), which is probably the reason why they were either < LoQ in the soil samples, or detected in lower proportions than in runoff (Figure 6). Conversely, HMV compounds are known to be more refractory to degradation processes (Leroy et al., 2015).

\subsection{Implications for SUDS design and maintenance}

Pollutant accumulation in SUDS soil may compromise the sustainability of these systems in two distinct ways: $(i)$ as explained previously, groundwater quality impairment might ultimately result from the exhaustion of the soil's retention capacities; (ii) high levels of pollution in soil might induce health and environmental hazards, which should be taken into account especially when SUDS are implemented within "multi-functional" areas delivering recreation opportunities (Zhou, 2014). Concerning the first point, the appearance of downward contaminant fluxes is a potential concern in urban catchments which generate high fractions of dissolved metals, such as residential areas with metallic roofs (Bressy, 2010). Localized infiltration at the surface is likely to aggravate the problem, since the actual drainage/infiltration area ratio appears to be higher than expected during small rainfall events, as a result of which most pollutant fluxes are concentrated in a narrow zone of the facilities (Tedoldi et al., 2017; Werkenthin et al., 2014). While "diffuse" inflow of runoff (e.g. in roadside swales or filter strips) is often assumed to guarantee a better distribution of infiltration fluxes - thus minimizing the risks of contaminant transfers -, the present results, as well as other studies (Flanagan et al., 2017), showed that locally uneven topography might substantially compromise the theoretical hydraulic behavior of the devices. In other words, there are de facto fewer differences than expected between facilities with "centralized" and "diffuse" inflow of water, in terms of functioning and maintenance operations.

Although downward pollutant fluxes appear difficult to anticipate through an assessment of soil contamination, it may be possible to prevent or at least mitigate this phenomenon via an amendment of the surface soil (e.g. humic substances, or specific sorbents). Notably, this should be undertaken if the original soil has poor sorption capacities, i.e. low CEC, organic matter and clay contents, like in the swale Chanteraines. Whatever its pedogenesis, the formation of an organic-rich horizon at the surface tends to increase the soil's retention potential, and may improve 
the lifespan of the devices. The present observations - which should be confirmed through further investigations - suggest that this essentially happens in large infiltration basins with spontaneous vegetation.

As regards the second issue, "unacceptable" contaminant concentrations in soil are generally defined with respect to supposedly generic thresholds, most of which originate from countryspecific regulatory guidelines. Inasmuch as the French regulations do not include such standards, criteria from other countries have been inventoried and gathered as Supplementary data. The values retained in the present study (Table 2) are part of the Canadian Soil Protection and Contaminated Sites Rehabilitation Policy, which states that "all soils contaminated beyond the generic criteria for use must be excavated and managed safely or else be treated". They were chosen as the "strictest" thresholds among the reviewed standards applying to "multi-functional" spaces, covering the whole range of analyzed contaminants (Fouchécourt et al., 2005).

None of these thresholds were exceeded in Sausset1, Sausset2, and Chanteraines; concentrations measured in Vitry were below the intervention thresholds likewise, except for $\mathrm{Cu}$, $\mathrm{Zn}$, and Chrysene in the upper $2.5 \mathrm{~cm}$. In Zone I, intervention appeared necessary over $10 \mathrm{~cm}$ in Greffiere and $30 \mathrm{~cm}$ in Dourdan, because of $\mathrm{Cu}$ and $\mathrm{Zn}$ contamination. Alfortville displayed unsustainable concentrations of $\mathrm{Cu}, \mathrm{Zn}, \mathrm{Cr}, \mathrm{Ni}$, and $\mathrm{Mo}$ in the upper 15 to $25 \mathrm{~cm}$ in Zone $\mathrm{I}$, and $5 \mathrm{~cm}$ in Zone II (along with Benzo[b]fluoranthene and Chrysene which also exceeded the intervention threshold in the surface sample). Among the seven study sites, the horizontal extent of "hazardous" contamination in the surface soil was shown to be restricted to $<25 \%$ of the total device area in Greffiere, Dourdan and Vitry, and 65\% in Alfortville (Tedoldi et al., 2017), as a consequence of non-uniform infiltration fluxes at the surface. Additionally, the present results indicated that the vertical extent did not exceed $30 \mathrm{~cm}$. In other words, the "typical" distribution of contaminants in SUDS soil - both laterally and vertically - notably reduces the onerousness of maintenance operations to be undertaken in these systems.

Table 2. Canadian intervention thresholds (expressed as total concentrations, in $\mathrm{mg} / \mathrm{kg}$ ) requiring soil remediation/excavation when exceeded (Fouchécourt et al., 2005).

\begin{tabular}{lllllllll}
\hline $\mathbf{C u}$ & $\mathbf{P b}$ & $\mathbf{Z n}$ & $\mathbf{C d}$ & $\mathbf{C r}$ & $\mathbf{N i}$ & $\mathbf{C o}$ & Mo & PAH \\
100 & 500 & 500 & 5 & 250 & 100 & 50 & 10 & $1-10^{\ddagger}$ \\
\hline
\end{tabular}

Different concentrations for each individual compound 
So as to identify the potential needs for soil maintenance, a simplified procedure may be defined based on the typical distribution of contaminants in the soil: $(i)$ collect 30- to 40-cm-deep soil cores at several locations in the inflow area, possibly considering visual observations of the water flow paths during wet weather, so as to identify a priori "hot spots" of contamination (Zone I), and at the opposite endpoint of the facility (Reference); (ii) in Zone I, composite and analyze bulk samples corresponding to the surface soil (0-3 cm) and other depths - with the maximum precision allowed by the analytical budget; (iii) in the reference zone, a unique sample made of the entire cores may be sufficient, as the contaminant profiles were generally found to be even; $(i v)$ in case any contaminant concentration exceeds the intervention threshold in Zone I, collect and analyze additional surface samples along a transect between the two zones, in order to "capture" the decrease in surface concentrations with increasing distance from the inlet. This simplified vision

of the vertical and lateral distribution of contaminants will then enable the delimitation of the extent of the polluted area, which may require remediation.

In any case, soil renewal or excavation should be undertaken with caution, since it might disrupt the interactions with the local ecosystem, and remove the benefits from both microfauna and plants, regarding PAH degradation for example (Gobat et al., 2013). Consequently, this should not be carried out in a proactive way or as a preventive measure. Additionally, maintenance operations should not expose deeper strata - with potentially lower sorption capacities and poorer biological activity - without bringing organic-rich vegetative soil at the surface, in order to ensure a sufficient retention of contaminants in the following years. This practice would be equivalent to considering a new "initial state" of the infiltration facility.

\section{CONCLUSIONS AND RESEARCH NEEDS}

After systematic investigation of the $\mathrm{Cu}, \mathrm{Pb}$ and $\mathrm{Zn}$ horizontal distribution in the surface soil of seven infiltration-based SUDS, the vertical distribution of various urban- and traffic-derived metals and PAH was assessed in two or three homogeneous zones, including the most and the least contaminated areas of the devices. Altogether, 116 samples were collected along entire soil profiles, and analyzed for metals, $\mathrm{PAH}$, and pedological parameters. In spite of noticeable differences between the characteristics and hydraulics of the study sites, contamination patterns generally consisted in significant surface buildup, followed by a decrease in concentrations with 
increasing depth. In several cases, metal contents appeared to be almost uniform over the upper 5 to $20 \mathrm{~cm}$, but they eventually reached reference values below 25 to $40 \mathrm{~cm}$ depth, even after $>20$ years of operation. The facilities with lowest contamination at the surface did not show a sharper decrease in $\mathrm{Cu}$ and $\mathrm{Zn}$ concentrations. When quantifiable, $\mathrm{CaCl}_{2}$-extractable concentrations were 2 to 3 orders of magnitude lesser than total concentrations, indicating that the mobility of metals was low in the soil of every device. As reported in previous studies, the decrease in PAH concentrations was not as clear as for metals, and the occurrence of spatial heterogeneities was more frequent, which in several cases might be the consequence of "historical" contamination of the parent material. Low molecular weight compounds, which are more subject to nonconservative processes, were rarely detected in the soil samples. Both spatial distributions and ranges of concentrations were consistent with literature findings on similar devices, except in one infiltration basin showing very high $\mathrm{Cr}, \mathrm{Ni}$, and Co contents.

Owing to the different retention mechanisms occurring during water infiltration, soil-based SUDS implemented in urban catchments exhibit an interesting potential towards runoff water pollution control, and contamination globally appears to be restricted to the upper horizons of soil. In four study sites, the pollution levels required excavation or remediation over 2.5 to $30 \mathrm{~cm}$, principally because of $\mathrm{Cu}$ and $\mathrm{Zn}$ contents. Nevertheless, the example of the other three infiltration systems, with moderate contamination at the surface, but still higher concentrations than the background values at the bottom, showed that non-exceedance of the intervention thresholds does not necessarily prevent from contaminant downward fluxes. Additionally, contaminant retention in the deeper horizons is subject to some uncertainty, especially since urban soils are known for being relatively heterogeneous: typical diminishing profiles might also be related to a decrease in the soil's sorption capacities, as suggested by the overall decrease in volatile matter content and cation exchange capacity with increasing depth. Further research should investigate the vertical evolution of sorption isotherms (e.g. via batch studies) in stratified SUDS soil so as to gain insight into this matter, as well as the expected lifetime of these devices. Maintenance of the surface soil may guarantee the regeneration of its retention potential, provided a new material with sufficient sorption capacities is subsequently amended at the surface; such a practice would be necessary over a limited area of the facilities, given the restricted extent of surface contamination. 


\section{ACKNOWLEDGEMENTS}

This research was carried out under the OPUR research program. The authors gratefully acknowledge OPUR partners for their financial support, as well as the French territorial collectivities which collaborated in the present study, by allowing the authors to perform soil samplings and measurements in their infiltration facilities.

\section{REFERENCES}

Achleitner, S., Engelhard, C., Stegner, U., Rauch, W., 2007. Local infiltration devices at parking sites - experimental assessment of temporal changes in hydraulic and contaminant removal capacity. Water Science and Technology, 55(4), 193-200.

Aryal, R. K., Furumai, H., Nakajima, F., Hossain, M. A., 2007. Vertical distribution and speciation of heavy metals in stormwater infiltration facilities: possible heavy metals release to groundwater. Water Practice and Technology, 2(2).

Barraud, S., Dechesne, M., Bardin, J.-P., Varnier, J.-C., 2005. Statistical analysis of pollution in stormwater infiltration basins. Water Science and Technology, 51(2), 1-9.

Boivin, P., Saadé, M., Pfeiffer, H. R., Hammecker, C., Degoumois, Y., 2008. Depuration of highway runoff water into grass-covered embankments. Environmental Technology, 29(6), 709720.

Bressy, A., Gromaire, M.-C., Lorgeoux, C., Saad, M., Leroy, F., Chebbo, G., 2014. Efficiency of source control systems for reducing runoff pollutant loads: Feedback on experimental catchments within Paris conurbation. Water Research, 57, 234-246.

Chocat, B., Ashley, R., Marsalek, J., Matos, M. R., Rauch, W., Schilling, W., Urbonas, B., 2007. Toward the sustainable management of urban storm-water. Indoor and Built Environment, 16(3), 273-285.

Chrysikopoulos, C. V., Kitanidis, P. K., Roberts, P. V., 1990. Analysis of one-dimensional solute transport through porous media with spatially variable retardation factor. Water Resources Research, 26(3), 437-446. 
Cousins, I. T., Beck, A. J., Jones, K. C., 1999. A review of the processes involved in the exchange of semi-volatile organic compounds (SVOC) across the air-soil interface. Science of the Total Environment, 228(1), 5-24.

Dechesne, M., Barraud, S., Bardin, J.-P., 2004. Spatial distribution of pollution in an urban stormwater infiltration basin. Journal of Contaminant Hydrology, 72(1-4), 189-205.

DiBlasi, C. J., Li, H., Davis, A. P., Ghosh, U., 2009. Removal and fate of polycyclic aromatic hydrocarbon pollutants in an urban stormwater bioretention facility. Environmental Science and Technology, 43(2), 494-502.

Dierkes, C., Geiger, W. F., 1999. Pollution retention capabilities of roadside soils. Water Science and Technology, 39(2), 201-208.

Dierkes, C., Lucke, T., Helmreich, B., 2015. General technical approvals for decentralised Sustainable Urban Drainage Systems (SUDS) - The current situation in Germany. Sustainability, 7(3), 3031-3051.

Ellis, J. B., Revitt, D. M., Lundy, L., 2012. An impact assessment methodology for urban surface runoff quality following best practice treatment. Science of the Total Environment, 416, 172-179.

Ferreira, M., Lau, S.-L., Stenstrom, M. K., 2013. Size fractionation of metals present in highway runoff: Beyond the six commonly reported species. Water Environment Research, 85(9), 793-805.

Flanagan, K, Tedoldi, D., Branchu, P., Gromaire, M.-C., 2017. Caractérisation du fonctionnement d'un ouvrage de gestion à la source du ruissellement de voirie : approche par modélisation hydrologique et par cartographie de la contamination du sol. La Houille Blanche, 3, $5-13$.

Fouchécourt, M.-O., Beausoleil, M., Lefebvre, L., Valcke, M., Belles-Isles, J.-C., Trépanier, M., 2005. Validation des critères $B$ et $C$ de la politique de protection des sols et de réhabilitation des terrains contaminés - Protection de la santé humaine. Rapport scientifique. Institut national de santé publique: Quebec.

Ganaye, A., Winiarski, T., Goutaland, D., 2007. Impact of infiltration basin on the vadose zone: relation between heavy metals retention and heterogeneity of glaciofluvial deposits. Proceedings of the $6^{\text {th }}$ Novatech Conference, Lyon, France. 
Gasperi, Johnny, Sebastian, C., Ruban, V., Delamain, M., Percot, S., Wiest, L., Mirande, C., Caupos, E., Demare, D., Diallo Kessoo Kessoo, M., Saad, M., Schwartz., Dubois, P., Fratta, C., Wolff, H., Moilleron, R., Chebbo, G., Cren-Olivé, C., Millet, M., Barraud, S., Gromaire, M.-C., 2014. Micropollutants in urban stormwater: occurrence, concentrations, and atmospheric contributions for a wide range of contaminants in three French catchments. Environmental Science and Pollution Research, 21(8), 5267-5281.

Gobat, J.-M., Aragno, M., Matthey, W., 2013. Le sol vivant. Bases de pédologie - Biologie des sols. Presses Polytechniques et Universitaires Romandes: Lausanne.

Göbel, P., Dierkes, C., Coldewey, W. G., 2007. Storm water runoff concentration matrix for urban areas. Journal of Contaminant Hydrology, 91, 26-42.

Göbel, P., Zimmermann, J., Klinger, C., Stubbe, H., Coldewey, W. G., 2008. Recommended urban storm water infiltration devices for different types of run-off under varying hydrogeological conditions. Journal of Soils and Sediments, 8(4), 231-238.

Gromaire-Mertz, M.-C., Garnaud, S., Gonzalez, A., Chebbo, G., 1999. Characterization of urban runoff pollution in Paris. Water Science and Technology, 39(2), 1-8.

Huber, M., Welker, A., Helmreich, B., 2016. Critical review of heavy metal pollution of traffic area runoff: Occurrence, influencing factors, and partitioning. Science of the Total Environment, 541, 895-919.

Ingvertsen, S. T., Cederkvist, K., Régent, Y., Sommer, H., Magid, J., Jensen, M. B., 2012. Assessment of Existing Roadside Swales with Engineered Filter Soil: I. Characterization and Lifetime Expectancy. Journal of Environmental Quality, 41, 1960-1969.

Jones, P. S., Davis, A. P., 2013. Spatial Accumulation and Strength of Affiliation of Heavy Metals in Bioretention Media. Journal of Environmental Engineering, 139(4), 479-487.

Kayhanian, M., Fruchtman, B. D., Gulliver, J. S., Montanaro, C., Ranieri, E., Wuertz, S., 2012. Review of highway runoff characteristics: Comparative analysis and universal implications. Water Research, 46(20), 6609-6624.

Kluge, B., Wessolek, G., 2012. Heavy metal pattern and solute concentration in soils along the oldest highway of the world - the AVUS Autobahn. Environmental Monitoring and Assessment, 184(11), 6469-6481. 
Le Coustumer, S., Moura, P., Barraud, S., Clozel, B., Varnier, J.-C., 2007. Temporal evolution and spatial distribution of heavy metals in a stormwater infiltration basin - Estimation of the mass of trapped pollutants. Water Science and Technology, 56(12), 93-100.

Leroy, M. C., Legras, M., Marcotte, S., Moncond'huy, V., Machour, N., Derf, F., Portet-Koltalo, F., 2015. Assessment of PAH dissipation processes in large-scale outdoor mesocosms simulating vegetated road-side swales. Science of the Total Environment, 520, 146-153.

Li, H., Davis, A. P., 2008. Heavy Metal Capture and Accumulation in Bioretention Media. Environmental Science and Technology, 42(14), 5247-5253.

Lind, B. B., Karro, E., 1995. Stormwater infiltration and accumulation of heavy metals in roadside green areas in Göteborg, Sweden. Ecological Engineering, 5(4), 533-539.

Martinez, C. E., Motto, H. L., 2000. Solubility of lead, zinc and copper added to mineral soils. Environmental Pollution, 107(1), 153-158.

Mikkelsen, P. S., Weyer, G., Berry, C., Waldent, Y., Colandini, V., Poulsen, S., Grotehusmann, D., Rohlfing, R., 1994. Pollution from urban stormwater infiltration. Water Science and Technology, 29(1-2), 293-302.

Mikkelsen, P. S., Häfliger, M., Ochs, M., Tjell, J. C., Jacobsen, P., Boller, M., 1996. Experimental assessment of soil and groundwater contamination from two old infiltration systems for road run-off in Switzerland. Science of the Total Environment, 189-190, 341-347.

Morrison, G. M. P., Revitt, D. M., Ellis, J. B., 1990. Metal speciation in separate stormwater systems. Water Science and Technology, 22(10-11), 53-60.

Morrow, A. C., Dunstan, R. N., Coombes, P. J., 2010. Elemental composition at different points of the rainwater harvesting system. Science of the Total Environment, 408(20), 4542-4548.

Napier, F., Jefferies, C., Heal, K. V., Fogg, P., d'Arcy, B. J., Clarke, R., 2009. Evidence of traffic-related pollutant control in soil-based Sustainable Urban Drainage Systems (SUDS). Water Science and Technology, 60(1), 221-230.

Norrström, A. C., Jacks, G., 1998. Concentration and fractionation of heavy metals in roadside soils receiving de-icing salts. Science of the Total Environment, 218(2-3), 161-174. 
Novozamsky, I., Lexmond, T. M., Houba, V. J. G., 1993. A single extraction procedure of soil for evaluation of uptake of some heavy metals by plants. International Journal of Environmental Analytical Chemistry, 51, 47-58.

Paus, K. H., Morgan, J., Gulliver, J. S., Leiknes, T., Hozalski, R. M., 2014. Assessment of the hydraulic and toxic metal removal capacies of bioretention cells after 2 to 8 years of service. Water, Air and Soil Pollution, 225(1), 1803.

Schroeder, R. A., 1995. Potential for chemical transport beneath stormwater runoff recharge (retention) basin for an industrial catchment in Fresno, California. Water-resources Investigations Report 93-4140. U.S. Geological Survey: Reston.

Sposito, G., 2008. The chemistry of soils, second edition. Oxford University Press: Oxford.

Strömvall, A.-M., Norin, M., Pettersson, T., 2007. Organic contaminants in urban sediments and vertical leaching in road ditches. In: G. Morrison \& S. Rauch (eds.), Highway and Urban Environment. Proceedings of the $8^{\text {th }}$ Highway and Urban Environment Symposium. Springer Verlag: Dordrecht, pp. 235-247.

Tedoldi, D., Chebbo, G., Pierlot, D., Kovacs, Y., Gromaire, M.-C., 2016. Impact of runoff infiltration on contaminant accumulation and transport in the soil/filter media of Sustainable Urban Drainage Systems: A literature review. Science of the Total Environment, 569-570, 904-926.

Tedoldi, D., Chebbo, G., Pierlot, D., Branchu, P., Kovacs, Y., Gromaire, M.-C., 2017. Spatial distribution of heavy metals in the surface soil of source-control stormwater infiltration devices Inter-site comparison. Science of the Total Environment, 579, 881-892.

US-EPA, 1999. Integrated Risk Information System (IRIS) database. Available at: https://www.epa.gov/iris. (accessed 11/11/16).

Werkenthin, M., Kluge, B., Wessolek, G., 2014. Metals in European roadside soils and soil solution - A review. Environmental Pollution, 189, 98-110.

Winiarski, T., Bedell, J.-P., Delolme, C., Perrodin, Y., 2006. The impact of stormwater on a soil profile in an infiltration basin. Hydrogeology Journal, 14(7), 1244-1251.

Zhou, Q., 2014. A Review of Sustainable Urban Drainage Systems Considering the Climate Change and Urbanization Impacts. Water, 6(4), 976-992. 


\section{ANALYTICAL STANDARDS}

ISO 10381-5, 2005. Soil quality - Sampling - Part 5: Guidance on the procedure for the investigation of urban and industrial sites with regard to soil contamination. International Organization for Standardization: Geneva.

ISO 10390, 2005. Soil quality - Determination of $p H$. International Organization for Standardization: Geneva.

ISO 10693, 2014. Soil quality - Determination of carbonate content - Volumetric method. International Organization for Standardization: Geneva.

ISO 11464, 2006. Soil quality - Pretreatment of samples for physico-chemical analysis. International Organization for Standardization: Geneva.

ISO 17294-2, 2016. Water quality - Application of inductively coupled plasma mass spectrometry (ICP-MS) - Part 2: determination of selected elements including uranium isotopes. International Organization for Standardization: Geneva.

ISO 22036, 2009. Soil quality - Determination of trace elements in extracts of soil by inductively coupled plasma-atomic emission spectrometry (ICP-AES). International Organization for Standardization: Geneva.

NF X31-130, 1999. Qualité des sols - Méthodes chimiques - Détermination de la capacité d'échange cationique (CEC) et des cations extractibles. Association française de normalisation: La Plaine Saint-Denis.

NF X31-147, 1996. Qualité des sols - Sols, sédiments - Mise en solution totale par attaque acide. Association française de normalisation: La Plaine Saint-Denis.

XP X33-012, 2000. Caractérisation des boues - Dosage des hydrocarbures aromatiques polycycliques (HAP) et des polychlorobiphényles (PCB). Association française de normalisation: La Plaine Saint-Denis. 


\section{SUPPLEMENTARY DATA}

Supplementary data include: (1) photographs of the study sites; (2) limits of quantification and analytical uncertainties for each analyzed contaminant; (3) thresholds for soil remediation from various countries; (4) additional results for the sites Dourdan, Alfortville, and Vitry.

\section{Study sites}

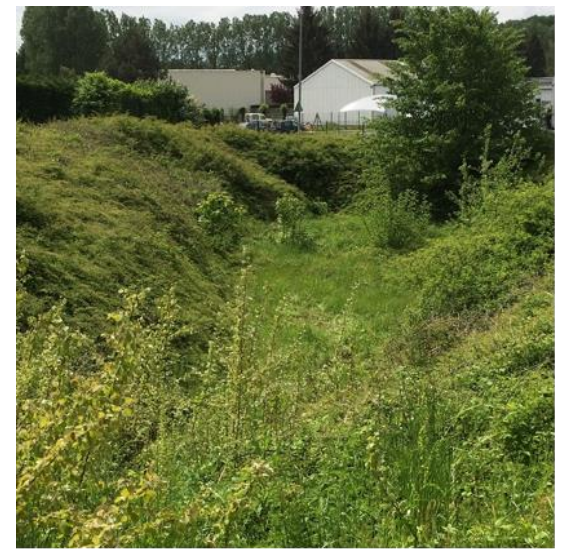

a. Dourdan

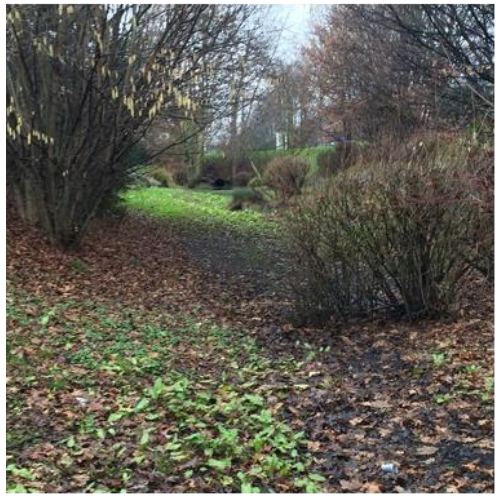

d. Alfortville, bottom

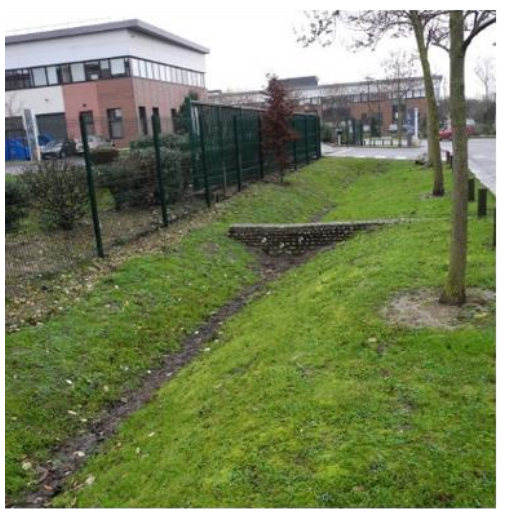

g. Chanteraines

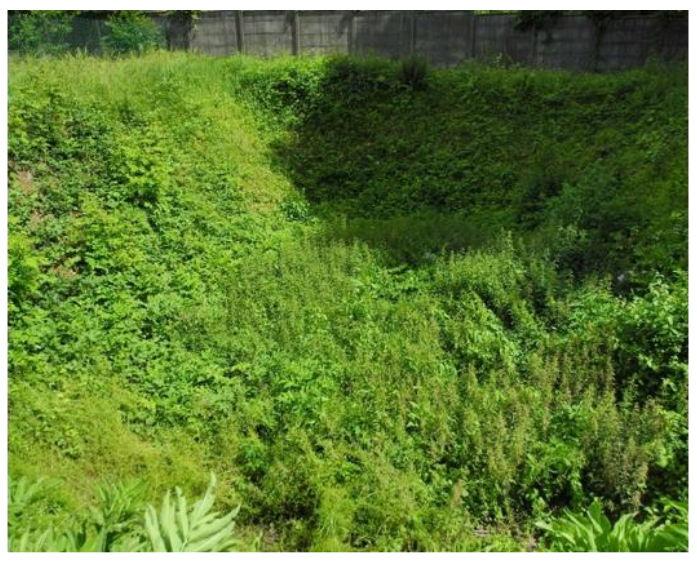

b. Greffiere

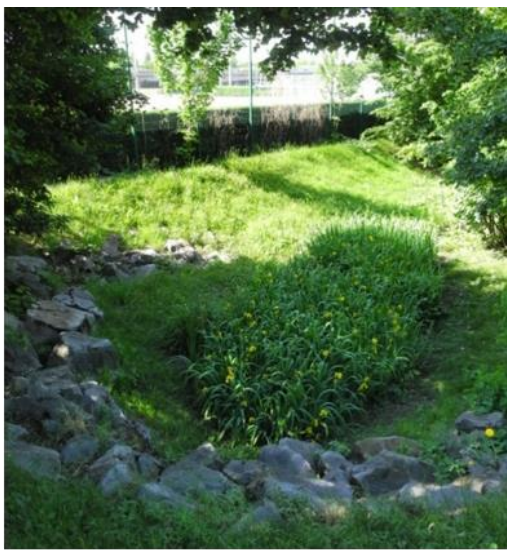

c. Alfortville, inflow area

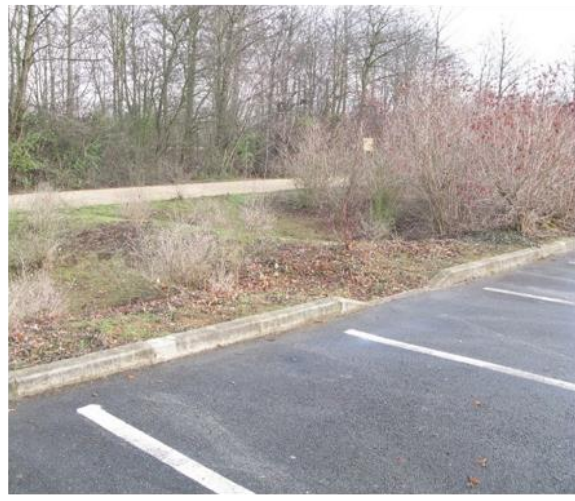

e. Sausset1

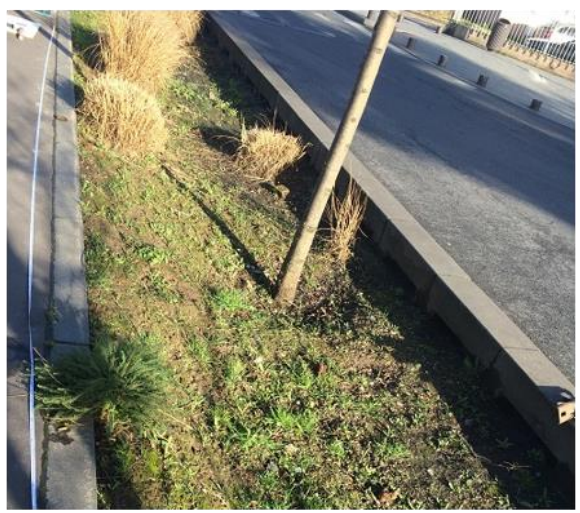

h. Vitry, general view

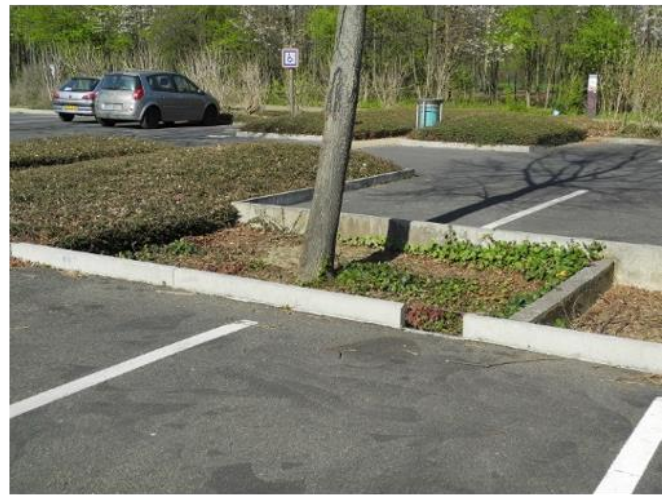

f. Sausset2

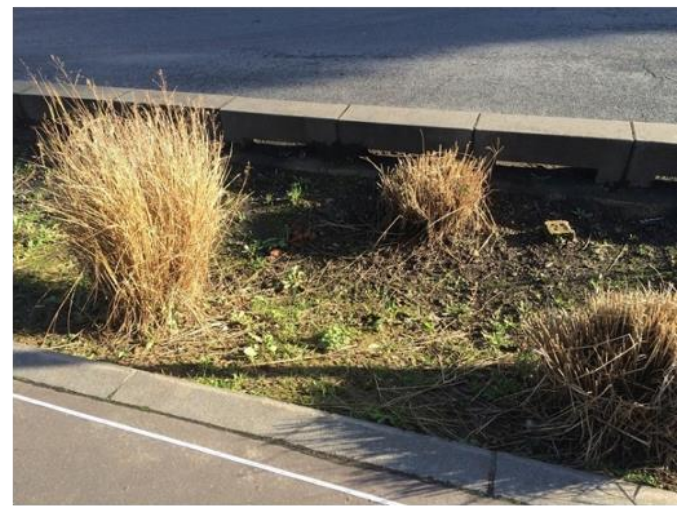

i. Vitry, lateral openings

Figure S1. Photographs of the study sites.

\section{Limits of quantification and analytical uncertainties}


The analytical uncertainties $U$ (derived from both intra- and inter-laboratory repeatability and reproducibility studies) are expressed as a function of the determined concentration $C$, so that $[C-U, C+U]$ is a $95 \%$ confidence interval for the real concentration, with:

$$
U=A \cdot C+B
$$

The coefficients $A[-]$ and $B[\mu \mathrm{g} / \mathrm{kg}]$ are indicated in the tables below for each analyzed contaminant.

a. Metals

\begin{tabular}{|l|l|l|l|l|l|l|l|l|}
\hline & $\mathbf{C u}$ & $\mathbf{P b}$ & $\mathbf{Z n}$ & $\mathbf{C d}$ & $\mathbf{C r}$ & $\mathbf{N i}$ & Co & Mo \\
\hline $\mathrm{LoQ}[\mu \mathrm{g} / \mathrm{kg}]$ & 1000 & 100 & 5000 & 20 & 2000 & 1000 & 1000 & 40 \\
\hline$A[-]$ & 0.04 & 0.062 & 0.04 & 0.062 & 0.112 & 0.04 & 0.054 & 0.057 \\
\hline$B[\mu \mathrm{g} / \mathrm{kg}]$ & 790 & 790 & 5940 & 10 & 2240 & 790 & 970 & 10 \\
\hline
\end{tabular}

b. $\mathrm{PAH}$

\begin{tabular}{|l|l|l|l|l|l|l|l|l|}
\hline & NAP & ACE & ACY & FLU & PHE & ANT & FLT & PYR \\
\hline LoQ $[\mu \mathrm{g} / \mathrm{kg}]$ & 20 & 10 & 30 & 5 & 10 & 5 & 10 & 10 \\
\hline$A[-]$ & 0.31 & 0.37 & 1.98 & 0.58 & 0.31 & 0.47 & 0.27 & 0.27 \\
\hline$B[\mu \mathrm{g} / \mathrm{kg}]$ & 4 & 2 & 0 & 1 & 2 & 1 & 11 & 2 \\
\hline
\end{tabular}

\begin{tabular}{|l|l|l|l|l|l|l|l|l|}
\hline & BaA & CHR & BbF & BkF & BaP & DBA & BPE & IPY \\
\hline LoQ $[\mu \mathrm{g} / \mathrm{kg}]$ & 10 & 50 & 10 & 50 & 10 & 20 & 50 & 10 \\
\hline$A[-]$ & 0.38 & 0.32 & 0.22 & 0.20 & 0.23 & 0.18 & 0.16 & 0.21 \\
\hline$B[\mu \mathrm{g} / \mathrm{kg}]$ & 2 & 10 & 9 & 1 & 9 & 4 & 10 & 2 \\
\hline
\end{tabular}

\section{Intervention thresholds from various countries $[\mathrm{mg} / \mathrm{kg}]$}

\begin{tabular}{|l|l|l|l|l|l|l|l|l|l|}
\hline & $\mathbf{C u}$ & $\mathbf{P b}$ & $\mathbf{Z n}$ & $\mathbf{C d}$ & $\mathbf{C r}$ & Ni & Co & Mo & $\sum$ PAH \\
\hline The Netherlands & 190 & 530 & 720 & 12 & 380 & 210 & 240 & 200 & 40 \\
\hline Switzerland & $\begin{array}{l}1000 \\
4^{\text {extr }}\end{array}$ & 1000 & $\begin{array}{l}2000 \\
5^{\text {extr }}\end{array}$ & $\begin{array}{l}20 \\
0.1^{\text {extr }}\end{array}$ & - & - & - & - & 100 \\
\hline Sweden & 200 & 300 & 700 & 1 & 250 & 150 & 60 & - & $7^{\dagger}$ \\
\hline Denmark & 500 & 400 & 1000 & 5 & 1000 & 30 & - & - & $15^{\dagger}$ \\
\hline Canada & 100 & 500 & 500 & 5 & 250 & 100 & 50 & 10 & $*$ \\
\hline
\end{tabular}

- Absence of threshold for this contaminant

extr Extractable concentrations

†Sum of the 7 carcinogenic PAH

Sum of Fluoranthene, Benzo[b]fluoranthene, Benzo[j]fluoranthene, Benzo[k]fluoranthene, Benzo[a]pyrene, Dibenz[ah] anthracene, and Indeno[1,2,3-cd]pyrene.

$* 1,5$, or $10 \mathrm{mg} / \mathrm{kg}$ according to the compound 


\section{Additional results}
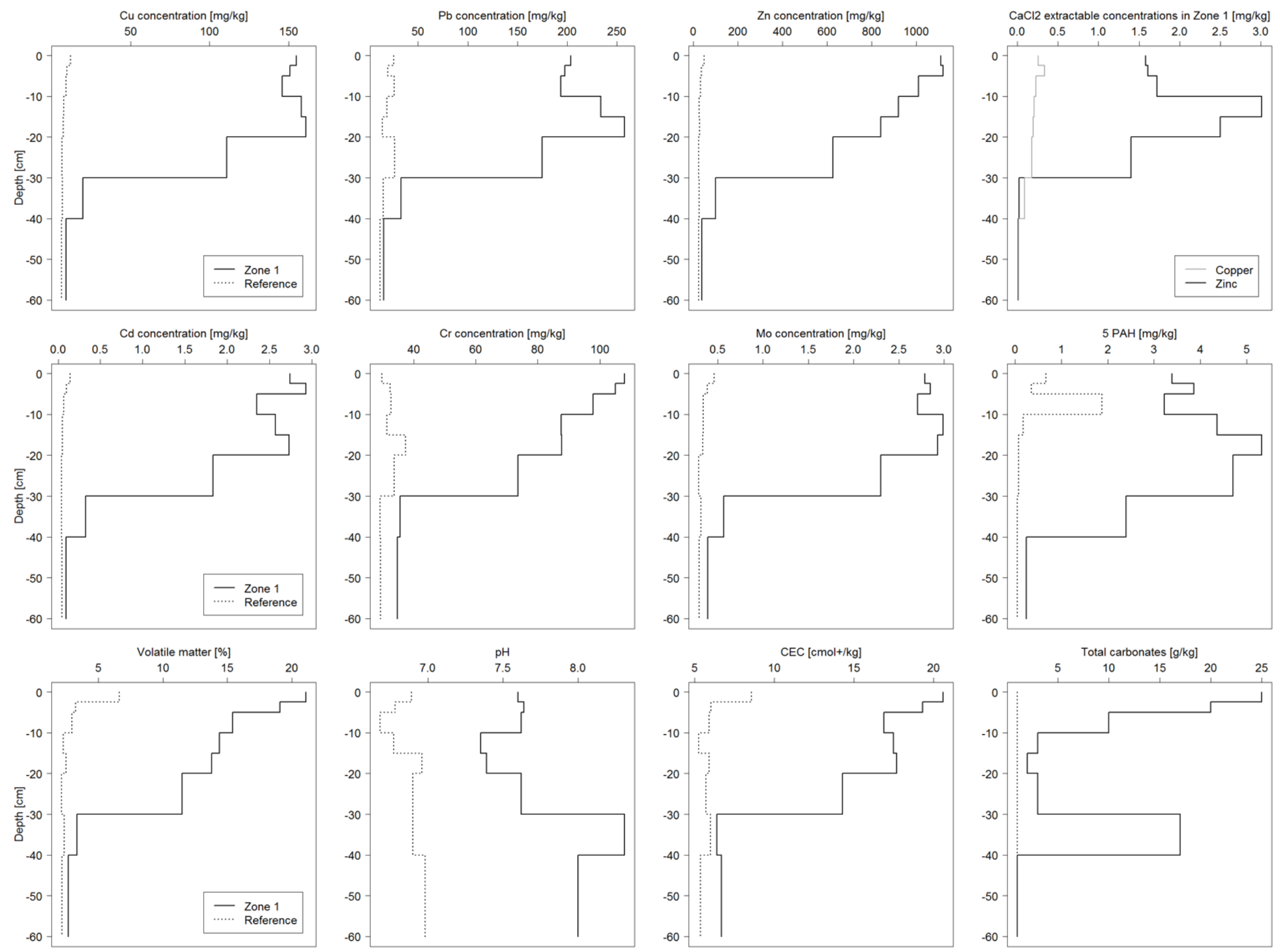

Figure S2. Complete results for the Dourdan site. 

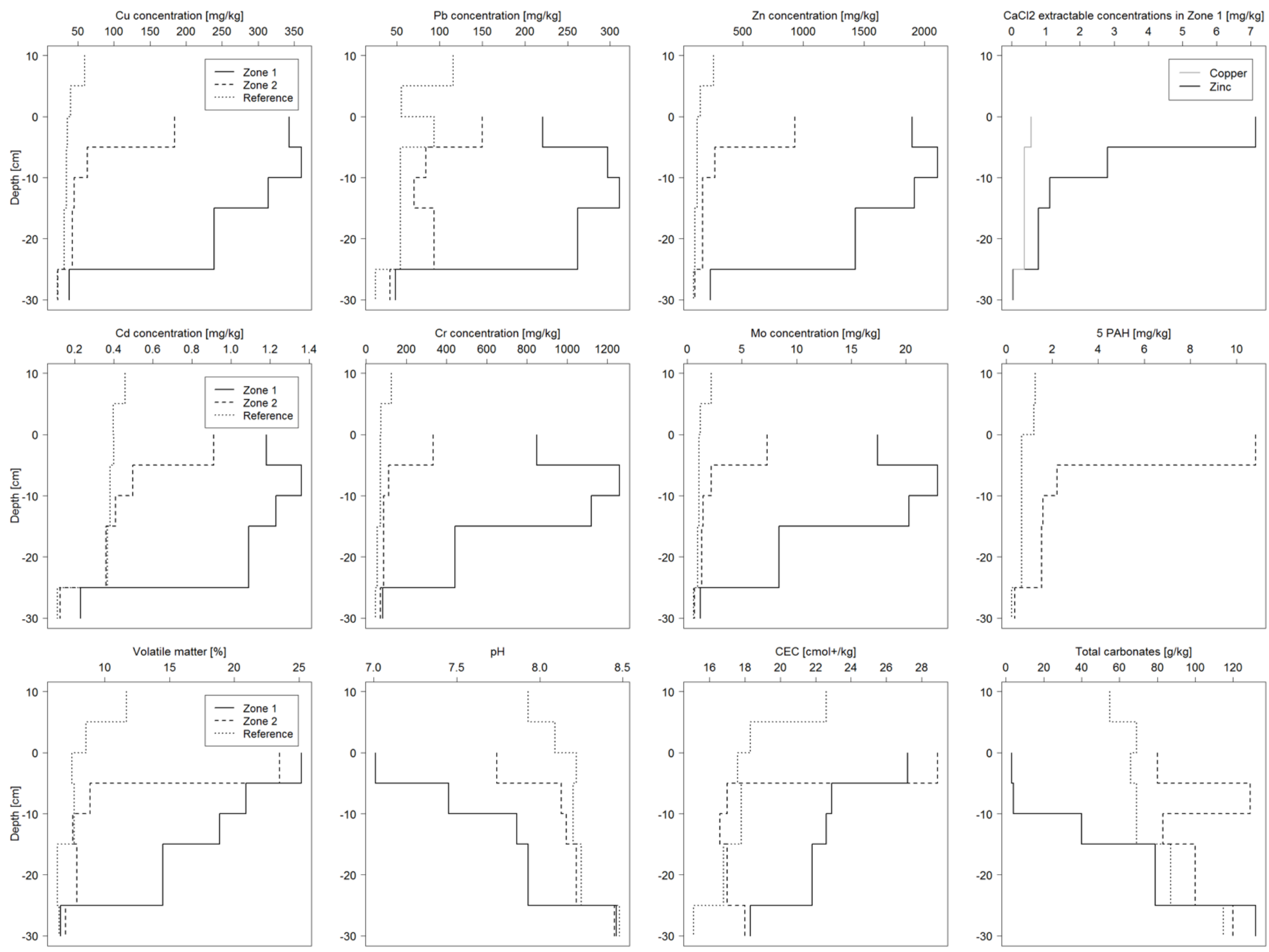

Figure S3. Complete results for the Alfortville site. 

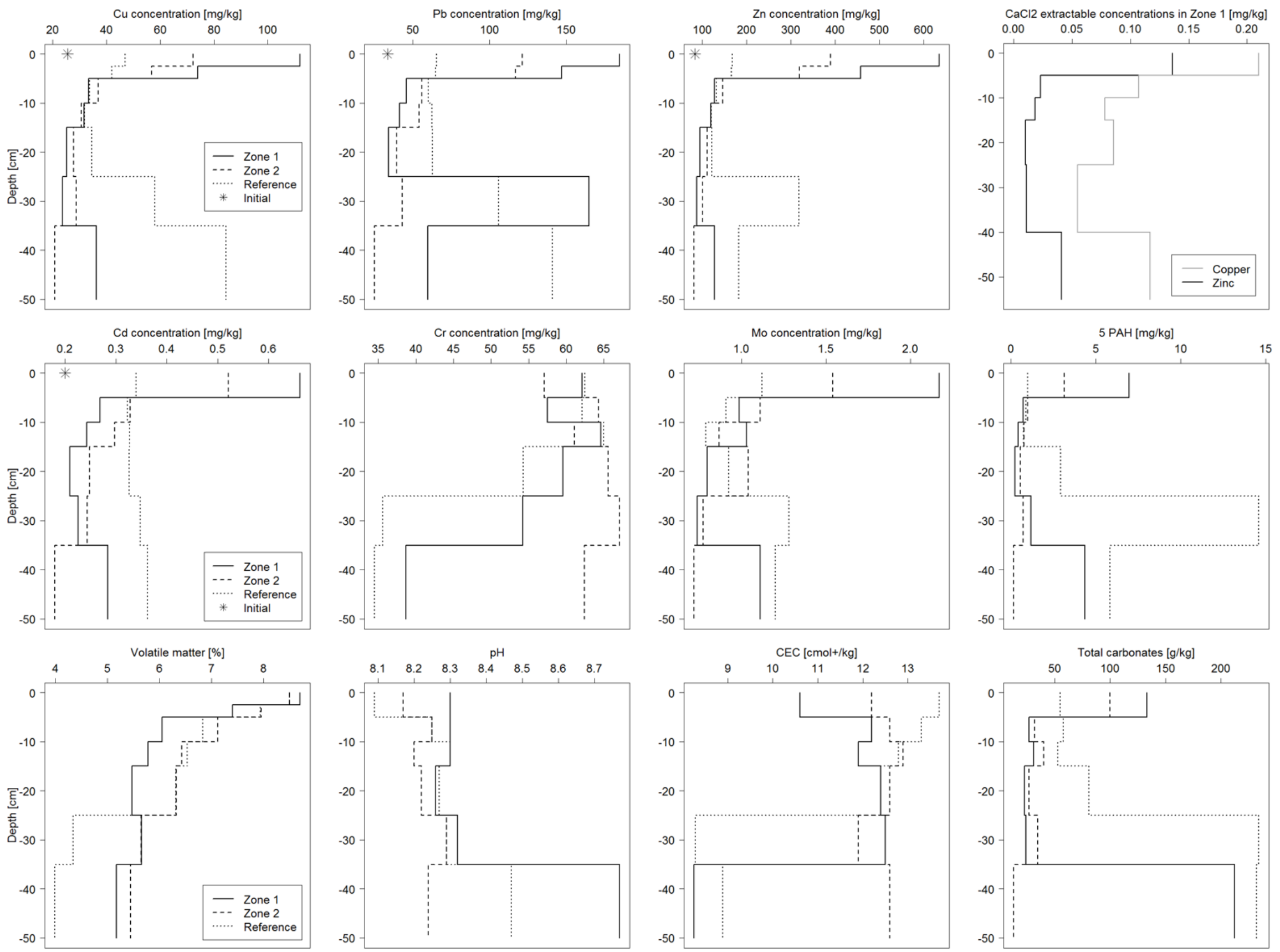

Figure S4. Complete results for the Vitry site. 
